\title{
What Should I Eat before Exercise? Pre-Exercise Nutrition and the Response to Endurance Exercise: Current Prospective and Future Directions
}

\author{
Jeffrey A. Rothschild *(D), Andrew E. Kilding and Daniel J. Plews \\ Sports Performance Research Institute New Zealand (SPRINZ), Auckland University of Technology, \\ Auckland 0632, New Zealand; andrew.kilding@aut.ac.nz (A.E.K.); daniel.plews@aut.ac.nz (D.J.P.) \\ * Correspondence: jeffrey.rothschild@aut.ac.nz
}

Received: 23 October 2020; Accepted: 11 November 2020; Published: 12 November 2020

\begin{abstract}
The primary variables influencing the adaptive response to a bout of endurance training are exercise duration and exercise intensity. However, altering the availability of nutrients before and during exercise can also impact the training response by modulating the exercise stimulus and/or the physiological and molecular responses to the exercise-induced perturbations. The purpose of this review is to highlight the current knowledge of the influence of pre-exercise nutrition ingestion on the metabolic, physiological, and performance responses to endurance training and suggest directions for future research. Acutely, carbohydrate ingestion reduces fat oxidation, but there is little evidence showing enhanced fat burning capacity following long-term fasted-state training. Performance is improved following pre-exercise carbohydrate ingestion for longer but not shorter duration exercise, while training-induced performance improvements following nutrition strategies that modulate carbohydrate availability vary based on the type of nutrition protocol used. Contrasting findings related to the influence of acute carbohydrate ingestion on mitochondrial signaling may be related to the amount of carbohydrate consumed and the intensity of exercise. This review can help to guide athletes, coaches, and nutritionists in personalizing pre-exercise nutrition strategies, and for designing research studies to further elucidate the role of nutrition in endurance training adaptations.
\end{abstract}

Keywords: cycling; running; carbohydrate; adaptations; periodization; fasting

\section{Introduction}

From Olympians to recreational exercisers, athletes of all levels face the same questions-what should I eat before exercise, and how does it affect my training? Despite being relevant to anyone performing exercise, many questions relating to the effects of nutritional intake on endurance training responses and adaptations remain unanswered.

The duration and intensity of exercise are the most important factors influencing the adaptive response to endurance training [1]. However, strategies altering nutrient availability before and during exercise can also impact training adaptations by modulating the exercise stimulus and/or cellular responses to the exercise-induced perturbations [2]. Specific strategies to alter nutrient availability can include exercising in the overnight-fasted state, restricting carbohydrate $(\mathrm{CHO})$ ingestion between training sessions, and increasing $\mathrm{CHO}$ ingestion before or during exercise [3]. Although performance may be improved following pre-exercise $\mathrm{CHO}$ ingestion [4,5], exercise undertaken with reduced availability of $\mathrm{CHO}$ can increase the activation of key signaling proteins compared with exercise performed with high $\mathrm{CHO}$ availability [6], potentially influencing longer-term training adaptations.

Among the intracellular signals comprising the endurance training response are mechanical stretch, reactive oxygen and nitrogen species (RONS), calcium flux, AMP:ATP ratio, and the availability 
of endogenous $\mathrm{CHO}$ and free fatty acids (FFA) $[7,8]$. These signals are affected by both the duration and intensity of an exercise session, and by the pre-exercise nutrition choices of an athlete (i.e., the size, type, and timing of the pre-exercise meal(s), Figure 1). Although some lines of evidence suggest ingesting $\mathrm{CHO}$ before exercise can negatively influence endurance training adaptations, contrasting findings have been reported. For example, ingesting $\mathrm{CHO}$ has decreased [9], increased [10], or had no effect [11] on the activity of the $5^{\prime}$ AMP-activated protein kinase (AMPK) following exercise. Similarly, training-induced improvements in maximal oxygen consumption $\left(\mathrm{VO}_{2 \max }\right)$ have been reported to increase [12], decrease [13], or remain unchanged [14] following 4-6 weeks of CHO-fed compared with fasted-state training. These contrasting findings can be a source of confusion and may explain why the beliefs and practices relating to the role and influence of pre-exercise nutrition vary so widely among coaches and athletes $[15,16]$. Accordingly, the purpose of this review is to highlight the current knowledge of the influence of pre-exercise nutrition ingestion on the metabolic, physiological, and performance responses to endurance training. We also highlight areas for practitioners where evidence is lacking, particularly regarding trained athletes, and suggest directions for future research.

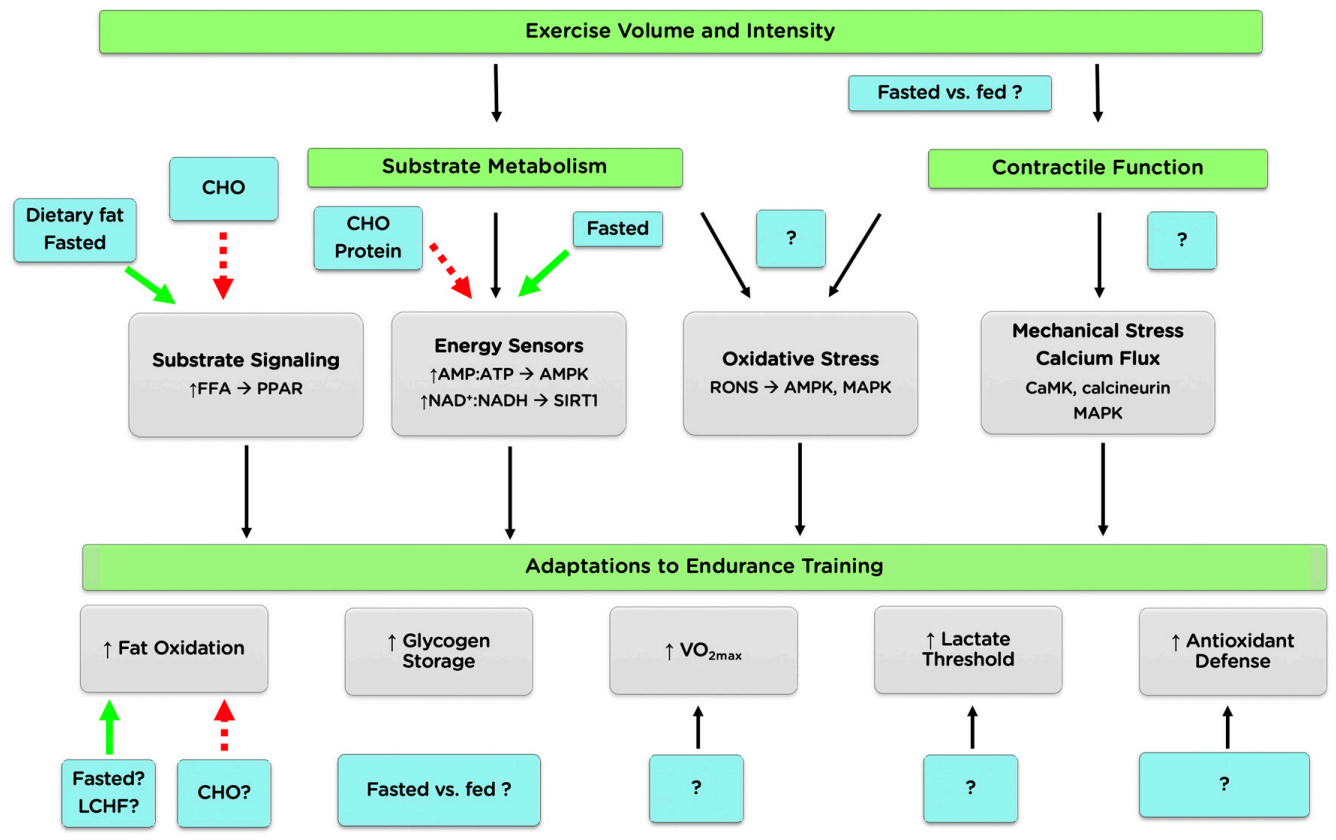

Figure 1. Schematic of areas where pre-exercise nutrition has the potential to impact the adaptive responses to endurance training. Green arrows suggest the potential to increase or augment specific signaling, and red dashed arrows suggest the potential to decrease or impair specific signaling. Abbreviations: AMPK, AMP-activated protein kinase; CaMK, calcium/calmodulin-stimulated protein kinase; $\mathrm{CHO}$, carbohydrate; FFA, free fatty acids; LCHF, low-CHO high-fat; MAPK, mitogen-activated protein kinase; $\mathrm{VO}_{2 \max }$, maximal oxygen consumption.

\section{Acute Responses to Pre-Exercise Nutrition Intake}

The vast majority of pre-exercise nutrition interventions have been conducted in an acute context. Although acute responses to training do not always correspond with long-term adaptations $[17,18]$, the accumulation over time of transient, exercise-induced changes in gene expression are thought to be the driving factor behind many adaptations to training [19]. Therefore, it is relevant to consider the acute effects of pre-exercise nutrition in addition to the longer-term adaptations.

\subsection{Metabolism and Substrate Oxidation}

The liver plays a key role in metabolic regulation during extended exercise [20]. Despite the $\sim 40 \%$ reduction in liver glycogen following an overnight fast [21], blood glucose concentration can 
be maintained at normal levels during exercise due to increased gluconeogenesis and/or decreased utilization of glucose in skeletal muscle [22,23]. However, fatigue during extended exercise is often associated with reduced blood glucose concentrations [24], supporting a critical role for liver glycogen in achieving optimal performance during extended exercise.

Exercising in the fasted-state generally allows higher levels of fat oxidation than exercise performed in the CHO-fed state during low-to-moderate intensity exercise [25] and can increase the relative intensity where maximal fat oxidation occurs [26]. Ingesting $\mathrm{CHO}$ before exercise increases plasma glucose and insulin levels, leading to a reduction in hepatic glucose output and an increase in skeletal muscle glucose uptake during exercise [27]. This can lower fat oxidation by decreasing plasma FFA availability via insulin-mediated inhibition of lipolysis [28], and also by inhibiting fat oxidation within the muscle due to an increased glycolytic flux [29]. Intramuscular triglycerides (IMTG) provide a key substrate for fat oxidation, primarily during exercise in the fasted state [30,31], although their use declines as the duration of exercise extends, while the oxidation of plasma FFA increases [32]. Up to $6 \mathrm{~h}$ may be required following a $\mathrm{CHO}$-rich meal for substrate oxidation and glucose homeostasis to return to levels observed during fasted-state exercise [33].

In contrast with exercise performed in the overnight-fasted state, which lowers hepatic but not muscle glycogen [34], restricting $\mathrm{CHO}$ between training sessions allows exercise to be undertaken with reduced muscle glycogen concentrations [35]. During exercise with low muscle glycogen there is an increase in the oxidation of fat [36,37] and amino acids [38,39], and a reduction in muscle glycogen breakdown $[36,40,41]$. During exercise undertaken with normal muscle glycogen levels, muscle glycogen breakdown is similar between fed and fasted-state exercise [31,42-44] and may be reduced when ingesting $\mathrm{CHO}$ during exercise [45].

The majority of research looking at fat oxidation has compared $\mathrm{CHO}$ to a placebo, but the use of pre-exercise protein ingestion represents an interesting and under-researched area. Consumption of protein before and during steady-state exercise did not affect FFA availability or whole body fat oxidation compared with fasted-state exercise commenced with normal [46] or lowered [47] muscle glycogen concentration, despite elevated insulin levels. This may be related to the increases in catecholamine levels during exercise, which are an important determinant of the adipose tissue lipolytic rate and can override the inhibition by insulin [48]. Although protein ingestion before exercising in a low-glycogen state has no effect on rates of muscle protein synthesis, it is plausible that it could reduce muscle protein breakdown during exercise [49]. It also appears possible that pre-exercise protein ingestion increases amino acid oxidation during exercise [49], but further quantification of its influence is needed.

To compare the influence of pre-exercise $\mathrm{CHO}$ ingestion, muscle glycogen levels, and glycemic index on substrate oxidation and AMPK activity, we pooled the results of 125 studies (available as supplementary online files) that included the relevant intervention groups (Figures 2-7). Together, these studies included 1245 subjects ( $12.8 \%$ female), with an average age, $\mathrm{BMI}$, and $\mathrm{VO}_{2 \mathrm{max}}$ of $25.4 \pm 3.1$ years, $23.2 \pm 1.4 \mathrm{~kg} \mathrm{~m}^{2}$, and $56.7 \pm 8.2 \mathrm{~mL} \mathrm{~kg}^{-1} \mathrm{~min}^{-1}$. Linear correlation analysis was used to calculate the correlation coefficient between variables, according to Pearson's product moment (r) using R statistical software. Pooled data are reported as mean \pm SD, with the level of statistical significance set at $p<0.05$.

\subsubsection{Effect of Exercise Duration}

The respiratory exchange ratio (RER - a measure of substrate oxidation) decreases with exercise duration, indicating an increasing reliance on fat oxidation as the duration of exercise extends [50]. Differences in RER between exercising in the fed vs. fasted state and following low vs. high glycemic index $\mathrm{CHO}$ remain largely similar throughout exercise, while the differences in RER between high and low starting muscle glycogen decrease as exercise duration extends (Figure 2). The latter could presumably be related to the greater utilization of muscle glycogen during exercise undertaken with higher levels of glycogen, leading to more similar levels during the later stages of exercise. This idea is supported by the pooled data, which show a strong correlation $(\mathrm{r}=0.89, p<0.001)$ between the differences in pre-exercise glycogen levels and differences in RER during exercise (Figure 3). 
A

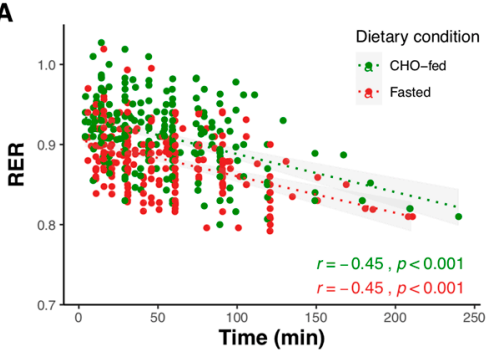

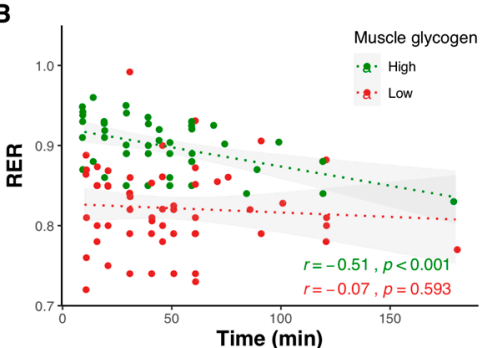

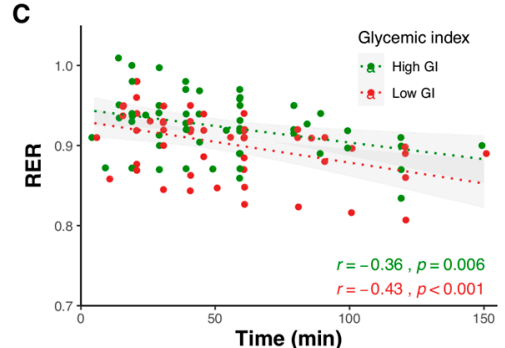

Figure 2. Substrate oxidation in relation to exercise duration for studies reporting respiratory exchange ratio (RER) at multiple time points comparing overnight-fasted and/or $\mathrm{CHO}$-fed exercise with normal muscle glycogen levels (A), exercise undertaken with high ( $471 \pm 208 \mathrm{mmol} \mathrm{kg}^{-1}$ dry mass) and low (232 $\pm 112 \mathrm{mmol} \mathrm{kg}^{-1}$ dry mass) muscle glycogen levels (B), and following high (82 \pm 10$)$ and low (36 \pm 9 ) glycemic index meals (C). Shaded areas represent $95 \%$ confidence intervals. Data were obtained by pooling results from 60 studies (see supplementary files for references).

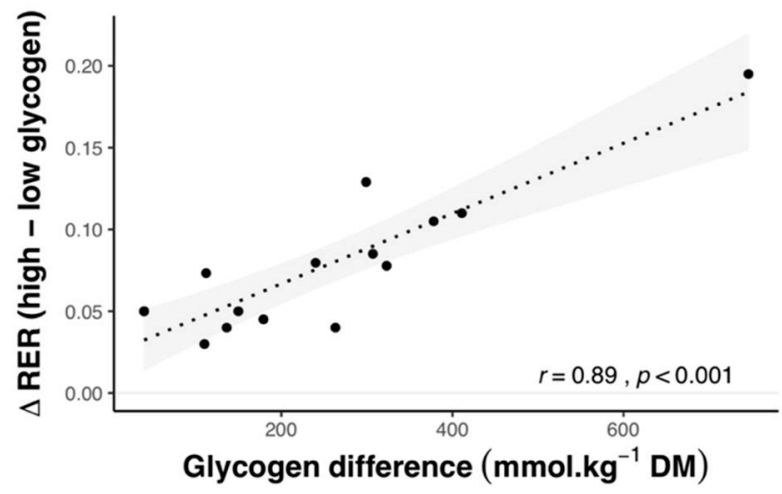

Figure 3. Correlation between differences in respiratory exchange ratio (RER) during exercise and differences in pre-exercise glycogen levels. Shaded area represents $95 \%$ confidence intervals. Data were obtained by pooling results from 13 studies that manipulated glycogen levels and reported RER for high- and low-glycogen trials (see supplementary files for references). DM = dry mass.

\subsubsection{Effect of Exercise Intensity}

Exercise intensity is well-established to influence substrate oxidation during exercise, with RER increasing with intensity [51]. Differences in RER between fed and fasted-state exercise are larger at lower intensities and decrease as intensity increases (Figure 4A,B). In contrast, exercise undertaken with low muscle glycogen maintains lower RER values compared with normal glycogen, despite increasing exercise intensity (Figure 4C,D). The glycemic index of the pre-exercise meal appears to have minimal effects on the relationship between intensity and substrate oxidation (Figure $4 \mathrm{E}, \mathrm{F}$ ).

\subsubsection{Effect of Carbohydrate Amount}

Several studies have directly compared varying amounts of $\mathrm{CHO}$ ingested before exercise, either showing no differences in substrate oxidation with varying amounts of pre-exercise $\mathrm{CHO}$ [5,52-54], or differences throughout all [55] or portions [56,57] of the exercise bout. When pooling a number of studies together, there is a weak positive relationship between the amount of CHO ingested and RER during subsequent exercise, while differences in RER between $\mathrm{CHO}$-fed and fasted-state exercise increase as the amount of $\mathrm{CHO}$ ingested is increased (Figure 5). 
A

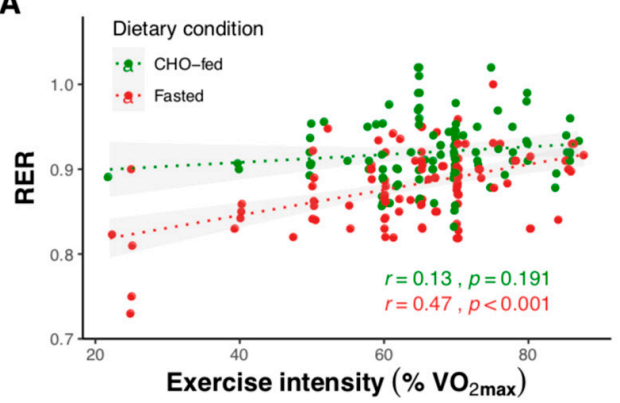

C

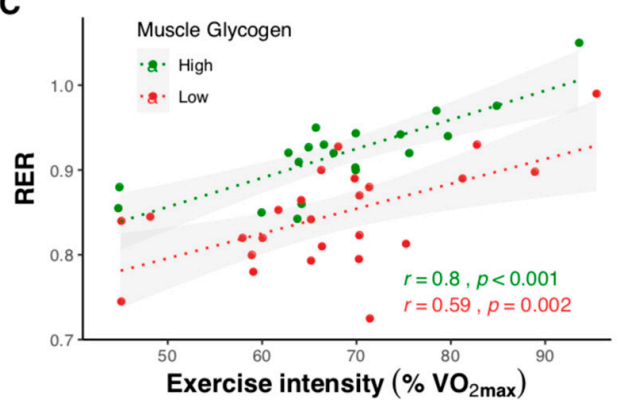

E

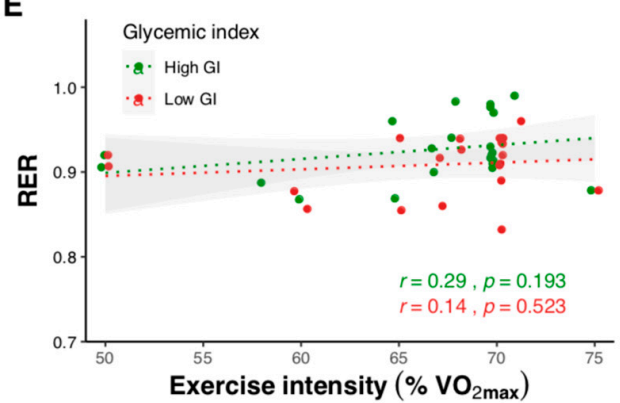

B

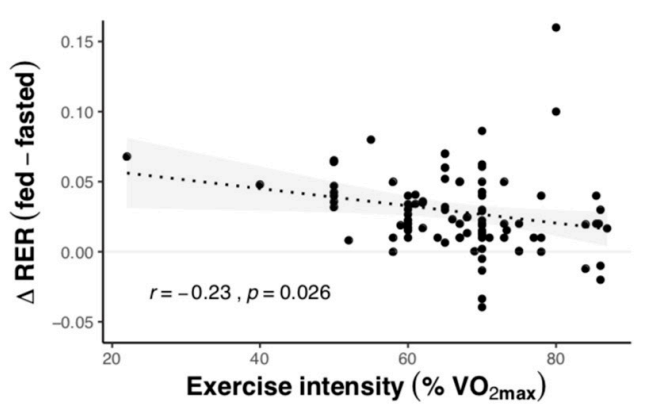

D

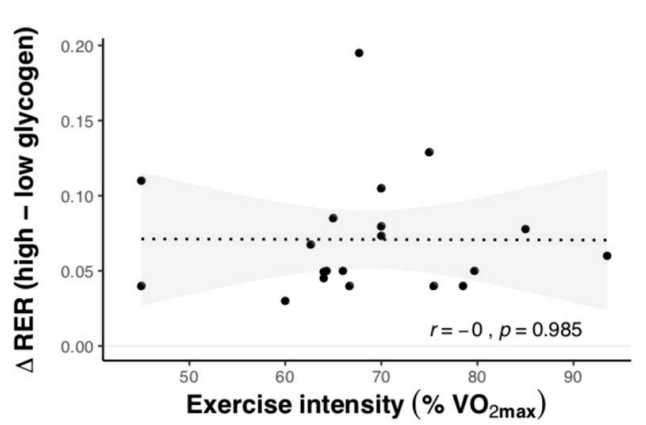

F

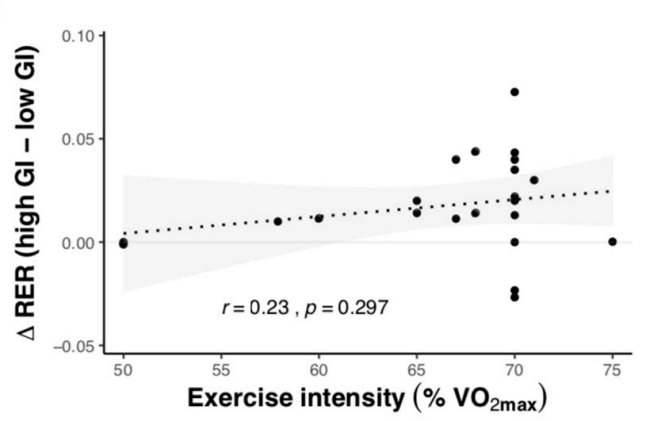

Figure 4. Substrate oxidation in relation to exercise intensity for studies comparing overnight-fasted and $\mathrm{CHO}$-fed exercise with normal muscle glycogen levels $(\mathbf{A}, \mathbf{B})$, exercise undertaken with high $\left(471 \pm 208 \mathrm{mmol} \mathrm{kg}^{-1}\right.$ dry mass) and low (232 $\pm 112 \mathrm{mmol} \mathrm{kg}^{-1}$ dry mass) muscle glycogen levels $(\mathbf{C}, \mathbf{D})$, and following high $(82 \pm 10)$ and low $(36 \pm 9)$ glycemic index meals (E,F). Shaded areas represent $95 \%$ confidence intervals. Data were obtained by pooling results from 103 studies (see supplementary files for references).
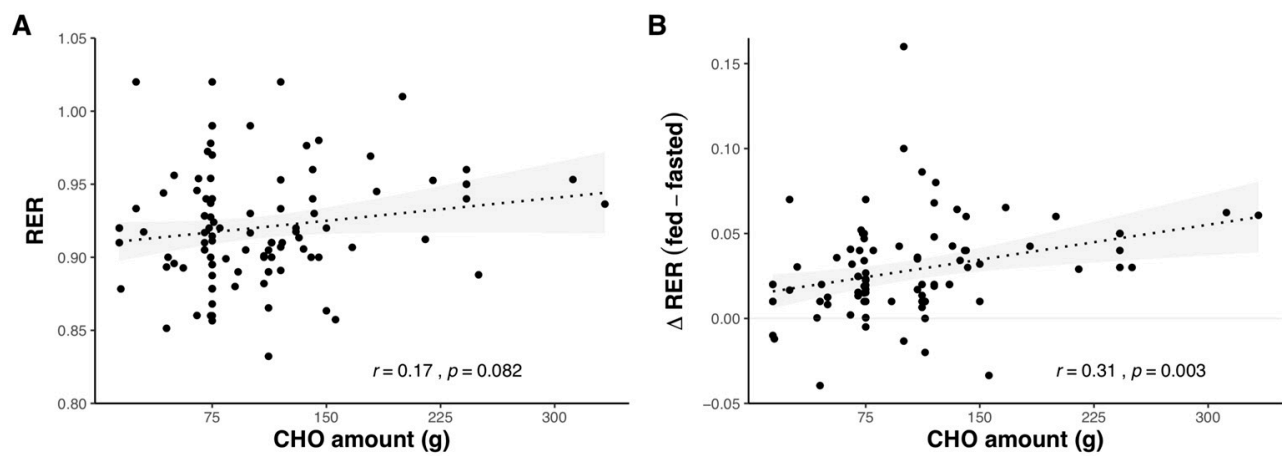

Figure 5. Substrate oxidation in relation to amount of carbohydrate $(\mathrm{CHO})$ consumed before exercise, as absolute RER value during exercise (A) and difference in RER between fed and fasted-state exercise (B). Shaded areas represent $95 \%$ confidence intervals. Data were obtained by pooling results from 76 studies (see supplementary files for references). 
A

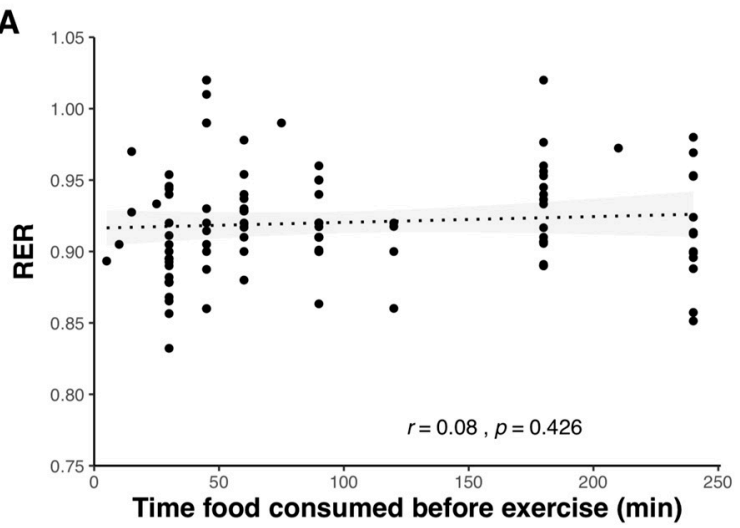

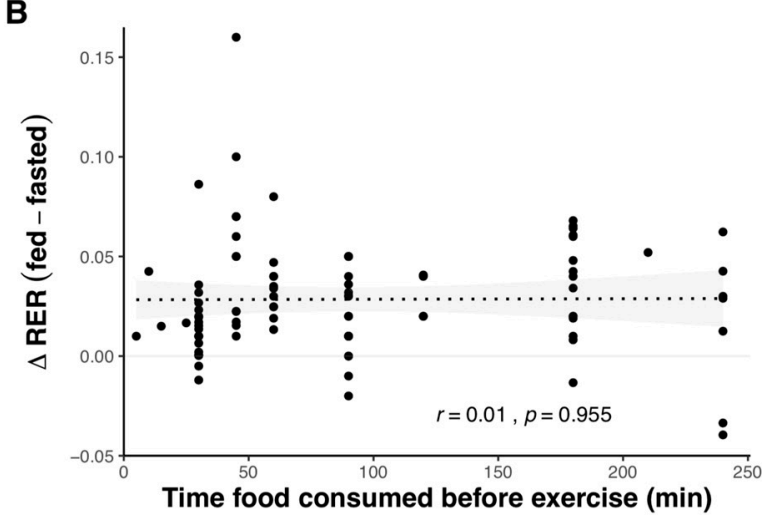

Figure 6. Substrate oxidation in relation to the time food was consumed before exercise, as absolute RER value during exercise (A) and difference in RER between CHO-fed and fasted-state exercise (B). Shaded areas represent $95 \%$ confidence intervals. Data were obtained by pooling results from 76 studies (see supplementary files for references).

A

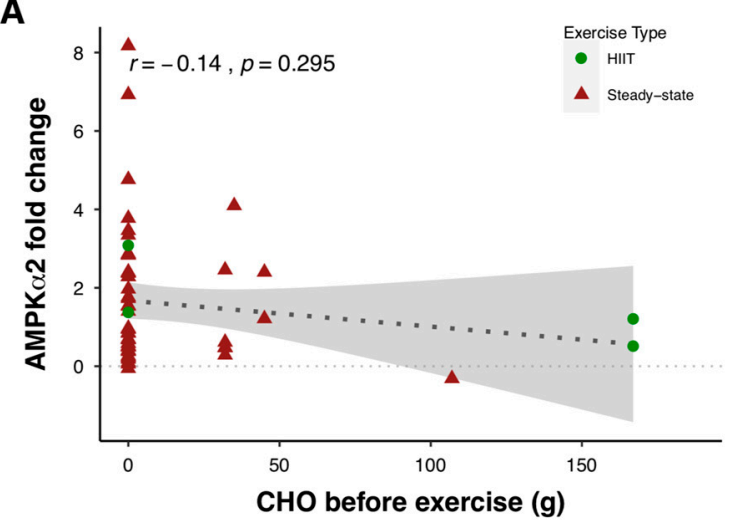

B

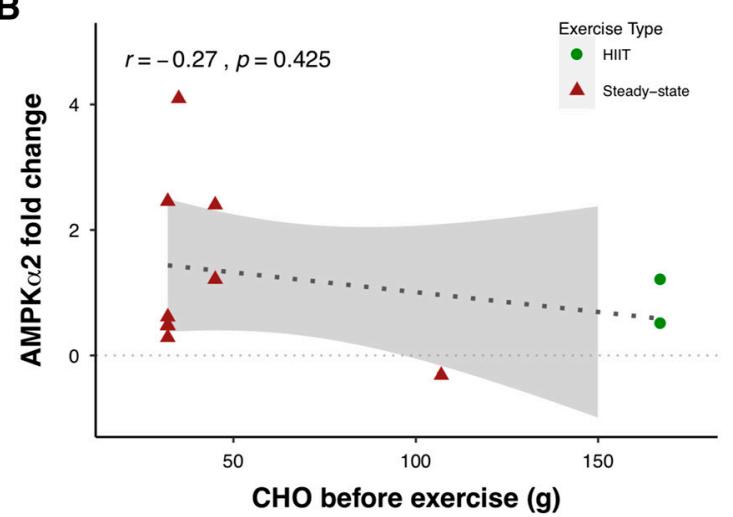

Figure 7. Relationship between $\mathrm{AMPK} \alpha 2$ activity during exercise (measured as fold-change from pre-exercise resting levels to immediately post-exercise) and carbohydrate $(\mathrm{CHO})$ intake before exercise including (A) and excluding (B) studies that tested in the overnight-fasted state. HIIT: high-intensity interval training. Shaded areas represent $95 \%$ confidence intervals. Data were obtained by pooling results from 22 studies (see supplementary files for references), which included 265 participants (6.0\% female), $25.1 \pm 2.8$ years, $\mathrm{VO}_{2 \max } 52.9 \pm 11.0 \mathrm{~mL} \mathrm{~kg}^{-1} \mathrm{~min}^{-1}$.

\subsubsection{Effect of Pre-Exercise Meal Timing}

The amount of time before exercise food is consumed is another factor that can influence metabolism and substrate oxidation, and studies have undertaken exercise in the fed state between 5 [58] and $240 \mathrm{~min}[59,60]$ post-prandial. Although direct comparisons of the influence of meal-timing are limited, no differences in substrate oxidation were found when the same meals were ingested 15,45 , or $75 \mathrm{~min}$ [61] and 30,60, or $90 \mathrm{~min}$ [62] before exercise. When consumed within $4 \mathrm{~h}$ of exercise, the amount of time prior to exercise does not have a meaningful impact on substrate oxidation (Figure 6).

\subsubsection{Summary and Future Directions}

During submaximal steady-state exercise, fat oxidation is generally higher in the overnight-fasted compared with $\mathrm{CHO}$-fed state. Although fat oxidation increases with exercise duration, fasted-state exercise increases fat burning throughout the duration of exercise compared with consuming $\mathrm{CHO}$ before exercise. However, as exercise intensity increases the difference in fat oxidation between $\mathrm{CHO}$-fed 
and fasted-state exercise diminishes. Fat oxidation is also higher when undertaking exercise with low, compared with normal muscle glycogen levels, with the differences maintained across varying exercise intensities but diminishing as the duration of exercise extends. While the amount of time before exercise food is consumed does not meaningfully influence substrate oxidation, greater amounts of $\mathrm{CHO}$ in the pre-exercise meal leads to greater differences in substrate oxidation between fed and fasted-state exercise. These findings are most applicable to moderately-trained males, who made up 87\% of study participants. Substrate metabolism may differ between males and females [63], with differences further affected by the female menstrual cycle [64] and the use of oral contraceptives [65]. Additionally, sedentary populations typically show no differences in post-exercise glucose, insulin, or FFAs between fasted and fed conditions [66], which is in contrast with trained athletes [67-69] who also show a greater capacity for fat oxidation compared with untrained or recreationally active populations [70].

Despite fasted-state training being performed by a large number of endurance athletes [15], there are potential negative implications from its use. Particularly for athletes doing a high volume of training, exercising in the overnight-fasted state could more likely lead to a negative energy balance, which can be associated with hormonal and immune dysfunction [71]. As a method of providing energy intake while still allowing higher levels of fat oxidation, future studies should examine the effects of a protein-rich breakfast on fat oxidation during exercise, in direct comparison with exercise following a $\mathrm{CHO}$-rich breakfast and in the overnight-fasted state. As this approach is currently utilized by few endurance athletes [16], it could be a useful tool for those who want to increase fat burning without incurring a large caloric deficit. The influence of various pre-exercise meals on gut comfort should also be investigated, as a large number of athletes perform fasted-state training to avoid gut discomfort [15]. Exercise-induced gastrointestinal distress is beyond the scope of this review but has been reviewed elsewhere [72,73].

\subsection{Cell Signaling}

Among the key intracellular signals influencing skeletal muscle adaptations to endurance training are changes in the AMP:ATP ratio, contraction-induced changes in mechanical strain, increased calcium flux, an increase in RONS, and the availability of endogenous CHO and FFA [7,8,74]. Nutritional intake has the potential to modify signaling across several of these pathways, primarily related to energy sensing and nutrient availability.

\subsubsection{Energy Sensing and the AMP-Activated Protein Kinase}

The 5' AMP-activated protein kinase (AMPK) is a cellular energy sensor that regulates cellular and whole-body energy balance by inhibiting ATP-consuming pathways and activating ATP-producing pathways [75]. Activation of AMPK can lead to a range of metabolic adaptations including increases in glucose uptake, glycolytic flux, fat oxidation, and mitochondrial biogenesis [76]. The degree of AMPK activation during exercise can be influenced by exercise intensity [77], training status [78], muscle glycogen [79], and nutrient availability [80].

When starting exercise with normal muscle glycogen levels, studies that have shown a blunting effect of $\mathrm{CHO}$ ingestion on AMPK- $\alpha 2$ activity $[9,81]$ have been at lower intensities than those showing no differences between $\mathrm{CHO}$-fed and fasted-state exercise [11,82]. Conversely, exercise that is undertaken with low, compared with normal muscle glycogen levels, has resulted in greater increases in the activity of AMPK- $\alpha 2$ following $1 \mathrm{~h}$ of steady-state endurance exercise at $65-70 \% \mathrm{VO}_{2 \max }$ [83-85], but similar increases in AMPK activity and/or phosphorylation were seen following both exhaustive and non-exhaustive high-intensity exercise undertaken with high and low muscle glycogen levels [86-88]. Therefore, ingesting $\mathrm{CHO}$ before exercise may dampen AMPK activity during low but not high-intensity exercise, and an intensity threshold may exist below which CHO ingestion could blunt AMPK signaling.

The $\mathrm{CHO}$ content of the pre-exercise meal size could also influence molecular signaling. Compared with exercising in the fasted state, consumption of $<70 \mathrm{~g} \mathrm{CHO}$ prior to exercise had no effect $[11,82]$ or even increased [10] skeletal muscle AMPK signaling following exercise compared with exercise 
performed in the fasted state. In contrast, ingesting 130-160 g of $\mathrm{CHO}$ before exercise reduced the exercise-induced increases in AMPK ${ }^{\text {Thr172 }}$ phosphorylation [89], with the phosphorylation of acetyl-CoA carboxylase (ACC) decreased [36] or unaffected [89]. When pooling a number of studies together, non-significant correlations can be observed between the exercise-induced increases in AMPK- $\alpha 2$ activation and $\mathrm{CHO}$ intake before exercise (Figure 7). Future studies that are designed to examine the relationships between meal size, exercise type and intensity, and AMPK activity are warranted.

Interpretation of the research comparing pre-exercise nutrition choices on AMPK activity during exercise is complicated by the small number of studies available, training status of participants, and specific markers being reported. For example, AMPK- $\alpha 2$ activity during exercise is reduced by short- and longer-term endurance training, making it difficult to compare between trained and untrained subjects $[78,90,91]$. Additionally, some studies report the phosphorylation of AMPK ${ }^{\text {Thr } 172}$, which reflects phosphorylation of both AMPK- $\alpha 1$ and $-\alpha 2$ subunits and may be less sensitive for detecting changes in AMPK activity that are only occurring in the $-\alpha 2$ subunit that is more responsive to exercise $[81,82,86]$. Further complicating interpretation of the available literature, several studies have shown a blunting effect of $\mathrm{CHO}$ ingestion on AMPK- $\alpha 2$ activity or AMPK ${ }^{\text {Thr172 }}$ phosphorylation, yet similar increases in phosphorylation of ACC, a downstream substrate of AMPK $[81,83,92]$. Similar increases in PGC-1 $\alpha$ mRNA expression following HIIT performed with low or high $\mathrm{CHO}$ availability have also been reported, despite phosphorylation of ACC being reduced by high $\mathrm{CHO}$ availability $[36,93]$. Furthermore, despite an attenuation of exercise-induced AMPK activation when ingesting $\mathrm{CHO}$ during a single bout of exercise [81], no differences in training adaptations were observed following 10 weeks of training with or without $\mathrm{CHO}$ ingestion during exercise [94]. These apparent discrepancies could be due to crosstalk between signaling pathways and/or the wide variability in exercise-induced changes in mRNA expression [95] and highlight the importance of looking at longer-term changes in mitochondrial content or function rather than acute changes in specific proteins.

\subsubsection{Contraction-Induced Signaling}

Another key intramuscular signal comes from increased calcium released during muscle contraction. Calcium-dependent transcriptional pathways play important roles in regulating fat oxidation, mitochondrial biogenesis, and muscle fiber-type changes via myocyte enhancer factor 2 (MEF2) and p38 mitogen-activated protein kinase (MAPK) [96-99]. Few studies have compared the effects of nutrition interventions on calcium-dependent, contraction-induced signaling pathways. There appear to be minimal effects of exercise performed in the fed vs. fasted-state or with varying levels of muscle glycogen $[36,87,89,100]$, but some evidence suggests p38 may be sensitive to nutrient status [101,102]. Although more research is needed, the independence of these pathways from nutritional influence could help to explain why similar longer-term changes could be observed when training under differing nutritional conditions.

\subsubsection{Substrate Signaling}

Exercise performed in the overnight-fasted state generally results in higher levels of FFA compared with CHO-fed exercise, and an inverse relationship is seen between FFA concentration and $\mathrm{CHO}$ oxidation during exercise [33]. In addition to acting as substrate for $\beta$-oxidation in the mitochondria, FFA also play a role in molecular signaling cascades that regulate fatty acid metabolism and mitochondrial biogenesis, via activation of peroxisome proliferator-activated receptors (PPAR), MAPKs, and sirtuin 1 [7,103-105]. Some studies have found differences in FFA between fed and fasted state throughout an entire bout of exercise $[50,106]$, while others have shown differences appearing from 20 [59], 30 [107], 45 [4], or $60 \mathrm{~min}$ [108] into exercise. These differences do not appear to show any pattern related to meal size, time of ingestion, or exercise intensity. Similar levels of FFA are found during exercise in the fasted-state and following ingestion of a high-fat meal $[60,109]$ or following pre-exercise protein ingestion with normal [46] and low [47] muscle glycogen levels. Although a 
high-fat diet, in the absence of exercise, can increase rates of fat oxidation during exercise, a high-fat intake by itself does not increase mitochondrial content or exercise performance without simultaneously engaging in exercise training [105]. Future studies are needed to determine if differences in FFA during CHO-fed vs. fasted-state can significantly alter training adaptations.

\subsubsection{Reactive Oxygen and Nitrogen Species}

Rather than simply being a byproduct of oxidative stress, RONS play a direct role in regulating the response to both acute exercise (e.g., muscle contractile function, glucose uptake, blood flow, and cell bioenergetics) and longer-term exercise training (e.g., mitochondrial biogenesis, muscle hypertrophy, angiogenesis, and redox homeostasis) [110]. Very little research exists looking at the influence of a pre-exercise meal on the oxidative stress response to a bout of exercise. At rest, a high-CHO meal can evoke a greater postprandial oxidative stress response compared with a high-fat meal [111], while the addition of olive oil to a meal reduced post-meal increases in oxidative stress markers, such as NADPH oxidase and 8-isoprostane, both of which have been associated with endurance training adaptations [112-114]. Acute and chronic fruit ingestion can dampen lipid oxidation during exercise [115], and fruit-derived phenolic compounds may promote muscle fiber-type transformation [116]. Whey protein can also impact the antioxidant defense system by enhancing activity of the endogenous antioxidant enzymes [117]. It is currently unknown how various pre-exercise meals affect oxidative stress in response to exercise and if there are any longer-term training implications.

\subsubsection{Summary and Future Directions}

Overall, it appears that ingesting small amounts of $\mathrm{CHO}(<75 \mathrm{~g})$ does not meaningfully impair mitochondrial signaling, but lower-intensity exercise may be more influenced by $\mathrm{CHO}$ ingestion than high-intensity exercise. Beyond the differences in exercise intensity and duration, interpretation of the existing literature is further challenged by several studies comparing the effects of fasted and $\mathrm{CHO}-\mathrm{fed}$ exercise that have provided $\mathrm{CHO}$ both before and during exercise $[9,30,118,119]$. This is relevant because $\mathrm{CHO}$ ingestion during exercise can reduce muscle glycogen breakdown [45], which itself may be a key signal for AMPK activity [79] and alter levels of TCA cycle intermediates [120].

Although crosstalk between signaling pathways exists, higher-volume endurance training is more likely to influence training adaptations through the contraction-induced signaling pathways, while higher-intensity training, which increases the AMP:ATP ratio, appears more likely to signal for mitochondrial biogenesis through energy-sensing pathways [121]. It is possible that there may be a threshold for the amount of $\mathrm{CHO}$ ingested before exercise $(\sim 75 \mathrm{~g})$, above which may impair intracellular (e.g., AMPK) signaling, independent of muscle glycogen levels. This is relevant as a large number of endurance athletes report consuming a small amount of $\mathrm{CHO}$-based foods before training [15]. It is also possible that the influence of $\mathrm{CHO}$ ingestion on AMPK signaling may be related to exercise intensity. Future research could seek to better understand the interplay between exercise intensity and the amount of $\mathrm{CHO}$ ingested before and/or during exercise, bearing in mind that interactions between $\mathrm{CHO}$ ingestion and exercise intensity may be different during continuous and intermittent exercise [122]. Additionally, a better understanding of the influence of pre-exercise nutrition on RONS signaling during exercise is needed.

\subsection{Performance}

Pre-exercise $\mathrm{CHO}$ ingestion has been found to generally enhance prolonged ( $>60 \mathrm{~min}$ ), but not shorter duration aerobic exercise performance [66]. However, ingesting CHO during exercise minimizes the differences between consuming $\mathrm{CHO}$ or a placebo prior to exercise [123-126]. The vast majority of studies comparing performance in the fed or fasted state have used steady-state endurance exercise [66], but similar effects of exercise duration are found with HIIT, as performance was improved in the fed state for 90 min of high-intensity intermittent running [68,127], but not short-duration HIIT [128-130]. However, one study showed a benefit of pre-exercise $\mathrm{CHO}$ ingestion on an exercise capacity test 
lasting 8-10 $\min$ [67]. Several studies have compared high-fat and high-CHO pre-exercise meals with minimal performance differences observed $[57,60,125,131]$.

\subsubsection{Amount, Type, and Timing of the Pre-Exercise Meal}

The amount of $\mathrm{CHO}(25-312 \mathrm{~g})$ consumed prior to exercise does not have a meaningful influence on time trial performance $[5,52,53,55]$, while the glycemic index appears to have only a small impact that is more likely to be observed in time-to-exhaustion, but not time-trial performance tests [132]. No differences in performance have been observed following pre-exercise ingestion of solid vs. liquid CHO [43], solid vs. gel-based CHO [133,134], or fast-food vs. sport supplements [135]. Timing of the pre-exercise meal has minimal effects when consumed 15, 45, or 75 min [61], 15 or 60 min [129], or 5 or $35 \mathrm{~min}$ [58] before exercise, but $\mathrm{CHO}$ ingested $30 \mathrm{~min}$ before exercise resulted in better performance than 120 min before exercise [67]. Taken together, performing fed vs. fasted exercise appears to have a far larger effect on exercise performance than the amount or timing of the meals, unless the difference in meal timing is at least $90 \mathrm{~min}$. There is some fear of hypoglycemia from consuming $\mathrm{CHO}$ between 30-60 min prior to exercise; however, despite occurring in a small number of cases, there does not appear to be any detrimental performance effects or any relationship between low blood glucose concentrations and performance [136].

\subsubsection{Athlete Perceptions and Behavior}

The perception of breakfast is also a consideration when comparing the acute performance effects of pre-exercise $\mathrm{CHO}$ intake and fasted exercise. Trained cyclists completed a $\sim 20 \mathrm{~min}$ cycling time-trial more quickly when they perceived that they had consumed breakfast ( $\mathrm{CHO}$ or placebo) prior to the start of the exercise, compared with a fasted exercise session [137], and there was a $4 \%$ improvement in $\sim 1 \mathrm{~h}$ time-trial performance when cyclists were told the placebo drink actually contained $\mathrm{CHO}$ compared with a blinded trial [138]. However, when a time-trial was preceded by $2 \mathrm{~h}$ of steady-state cycling, there were no placebo effects observed [139], suggesting placebo effects may be minimized with longer exercise durations. When undertaking exercise with reduced muscle glycogen levels, the perception of $\mathrm{CHO}$ availability augmented HIIT capacity, although performance was not restored to that of $\mathrm{CHO}$ consumption [140]. In a survey of endurance athletes, $26 \%$ agreed and $51 \%$ disagreed with the statement, "the quality of my workout is the same whether I eat or do not eat beforehand" [15], making it likely that a large inter-individual variation exists with regard to the perception of breakfast and its influence on performance.

\subsubsection{Summary and Future Directions}

Overall, the importance of consuming $\mathrm{CHO}$ before exercise increases as the exercise duration increases and exercising in the fed vs. fasted state appears to have a far greater effect on performance than the size or timing of the meals. To better understand the influence of pre-exercise energy availability vs. $\mathrm{CHO}$ availability and its effects on HIIT, future studies should compare fed vs. fasted exercise, along with pre-exercise protein ingestion, in the absence of $\mathrm{CHO}$, prior to both HIIT and steady-state performance tests.

\section{Training Adaptations}

The majority of research looking at pre-exercise nutrition interventions has been in relation to a single exercise session, with far fewer studies looking at the impact on training adaptations. This is relevant because acute responses to exercise do not always correspond with long-term adaptations. For example, increased fat oxidation observed when training with low vs. high $\mathrm{CHO}$ availability does not translate into longer-term increases in fat-burning capacity [141,142]. Likewise, blunting key mitochondrial signaling proteins with $\mathrm{CHO}$ ingestion during acute exercise did not impair training-induced improvements in performance or mitochondrial biogenesis [81,94]. Therefore, it is 
important to understand the changes that occur with chronic training rather than an acute bout of exercise alone.

\subsection{Skeletal Muscle Adaptation}

Of the studies examining the effects of longer-term ( $>4$ weeks) training in the fasted state on endurance adaptations [12-14,143-145], only one [144] has used endurance-trained subjects. Furthermore, almost all studies using moderate-intensity continuous endurance training in the fasted state also provided the fed groups with $\mathrm{CHO}$ during exercise, which can independently influence both acute [120] and chronic [93] responses to exercise. Other studies have examined pre-exercise $\mathrm{CHO}$ supplementation, though not necessarily in the overnight-fasted state and using untrained subjects [146,147]. Additionally, fasted state training has been used as part of studies comparing low vs. high muscle glycogen [148] and once vs. twice daily training [149]. Therefore, making comparisons across studies is challenged by the variety of methods that have been used to compare high vs. low $\mathrm{CHO}$ availability around training sessions (Figure 8).

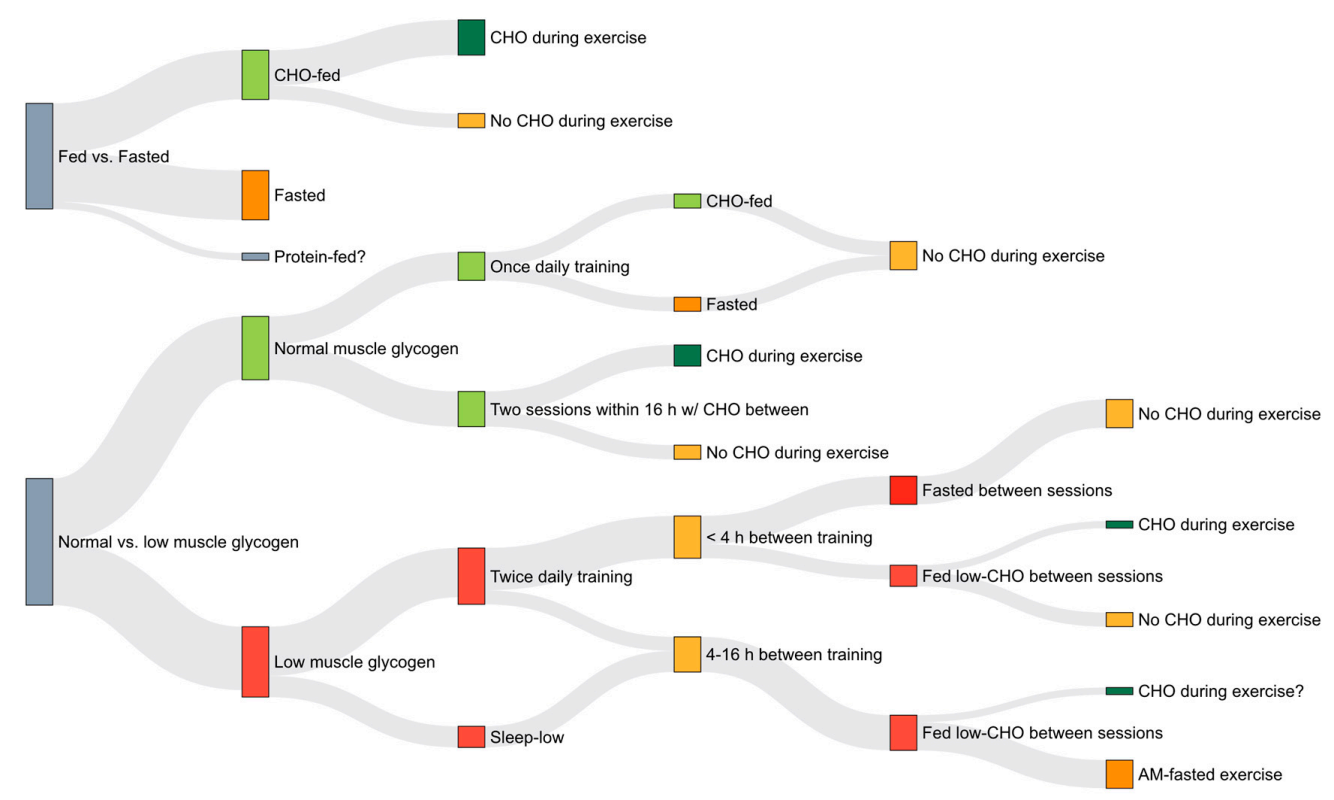

Figure 8. Comparison of the various methods of altering $\mathrm{CHO}$ availability used in training studies. Protocols used to commence training with a reduced availability of endogenous carbohydrate include overnight fasting, and training twice within a $24 \mathrm{~h}$ period consuming low-CHO nutrition between sessions or remaining in the fasted state. Some studies have fed carbohydrate during exercise, while others have not. Thickness of the line is related to the number of studies using a given approach. Question marks represent areas yet to be studied. Created from [12-14,31,35,93,141-145,148-153], which included 307 participants (10.7\% female), $26.3 \pm 4.2$ years, $V_{2 \max } 53.2 \pm 11.0 \mathrm{~mL} \mathrm{~kg}^{-1} \mathrm{~min}^{-1}$.

\subsubsection{Substrate Usage}

One of the reasons athletes perform training sessions in the fasted state is a desire to increase fat oxidation during exercise [15]. As discussed above (Section 2.1), fat oxidation is higher during an acute bout of exercise performed in the overnight-fasted, compared with the CHO-fed state, and with low compared with high muscle glycogen. Despite these differences, most studies have found no differences in fat oxidation following 4-6 weeks of fed or fasted-state training when tested in the fed $[13,14,145]$ or fasted $[31,146]$ state. Similar findings have been reported in the "sleep-low" context, where fat oxidation is increased during fasted training sessions performed with low muscle glycogen compared with exercising in the fed-state, but no differences in fat oxidation were observed following one [148], three [142], or four [141] weeks of training when tested in the fed state. However, it is 
possible that longer time periods of fasted training may be needed before relevant differences in fat oxidation would be observed, as proteins involved in fat oxidation have been increased following fasted, but not fed-state training [12,14]. Studies that have reported improvements in fat oxidation following training with low compared with normal muscle glycogen tested subjects in the fasted state and trained twice-daily with only water ingested between the sessions $[149,150]$. Though speculative, these differences could be related to FFA signaling, which are increased during exercise and increased even further if no food is ingested in the hours following exercise [105]. Finally, IMTG usage during exercise was increased after 6 weeks of fasted (but not fed) training when tested in the fasted state [145], but there were no differences when tested in a fed state, while also providing additional CHO [14]. Taken together, it appears that increases in fat oxidation following fasted-state or low-glycogen training may not be relevant during typical racing conditions when consuming $\mathrm{CHO}$ before and during exercise, but more studies in endurance-trained athletes are needed to compare acute and chronic changes.

\subsubsection{Mitochondrial Markers}

A key feature of the adaptive response to endurance training are changes in the activity of enzymes involved in the tricarboxylic acid (TCA) cycle and the $\beta$-oxidative pathway [154]. Activity of citrate synthase (CS) is the most widely used biomarker of mitochondrial content in skeletal muscle because of the strong correlation between resting CS activity and resting mitochondrial content when measured using the "gold standard" transmission electron microscopy (TEM) [155]. Similar changes in CS activity have been observed between fasted and fed-state training following 4-6 weeks of moderate-intensity training $[12,13]$ and HIIT $[143,146]$. A key enzyme of the $\beta$-oxidative pathway, $\beta$-hydroxyacyl coenzyme A dehydrogenase ( $\beta$-HAD), is also generally not impacted by pre-exercise nutrition $[12,13,143]$. However, one study has shown an increase in both CS and $\beta$-HAD only with fasted, but not CHO-fed training [145]. It is possible that this difference may be related to the very large amount of $\mathrm{CHO}$ ingested in the fed-training group $\left(\sim 2 \mathrm{~g} \mathrm{~kg}^{-1} 90 \mathrm{~min}\right.$ prior and $1 \mathrm{~g} \mathrm{~kg}^{-1} \mathrm{~h}^{-1}$ during exercise), as other studies showing similar adaptations between fed and fasted training used smaller (e.g., $1-1.5 \mathrm{~g} \mathrm{~kg}^{-1} \mathrm{CHO}$ ) pre-training meals $[13,143]$. Increases in succinate dehydrogenase activity following twice-daily training were blunted when ingesting $\mathrm{CHO}$ before and during the second workout, which was commenced with lowered muscle glycogen [93], suggesting a strong, and potentially underappreciated influence of ingesting $\mathrm{CHO}$ during exercise that adds complexity when interpreting the current literature.

Greater increases in CS have been reported in two studies that had subjects train twice-daily every other day, inducing low muscle glycogen during the second bout of exercise, compared with once-daily training with normal muscle glycogen $[35,150]$. In these studies, the two sessions were $1-2 \mathrm{~h}$ apart and subjects received only water between sessions. In contrast, other studies using twice-daily training but feeding low- or high-CHO meals between sessions found similar training-induced increases in CS activity between groups $[151,153]$. When comparing two different "train-low" protocols ( $2 \mathrm{~h}$ vs. $15 \mathrm{~h}$ between low-glycogen training sessions), greater elevations in acute signaling and mitochondrial adaptations were observed when training with $2 \mathrm{~h}$ between sessions without ingesting any food $[152,156]$. Thus, it appears that remaining in the fasted state following the first bout of exercise may be an important factor in the augmented adaptations observed following twice-daily training.

Overall, the exercise training itself seems to be the primary driver of changes in mitochondrial content, though very large pre-exercise meals $(>1.5 \mathrm{~g} / \mathrm{kg} \mathrm{CHO}$ ) and $\mathrm{CHO}$ ingestion during exercise may have blunting effects on some signaling pathways, possibly related to the interactions between AMPK and glycogen [79]. Future research should explore the effects of pre-exercise nutrition choices on contraction-induced and RONS signaling pathways.

\subsection{3. $\mathrm{VO}_{2 \max }$ and Peak Aerobic Power}

Studies comparing fasted and fed training have reported no differences in $\mathrm{VO}_{2 \max }$ following 4 weeks of sprint interval training (SIT) [144], 6 weeks of aerobic training [14,145], and 3 weeks of mixed 
intensity training [157]. However, greater training-induced increases in $\mathrm{VO}_{2 \mathrm{max}}$ have also been reported following both fasted vs. fed-state training [13] and fed vs. fasted-state training [12]. Reasons for these divergent findings are unclear, as both studies used untrained participants performing 4-6 weeks of steady-state aerobic training. Similar improvements in $\mathrm{VO}_{2 \max }$ and peak power were seen in untrained men following 8 weeks of HIIT with or without prior $\mathrm{CHO}$ [146], and following exercise undertaken with low or high muscle glycogen levels in trained and untrained athletes [35,93,153,158,159].

\subsubsection{Summary and Future Directions}

Pre-exercise nutrition intake would not be expected to have an effect on $\mathrm{VO}_{2 \mathrm{max}}$ (which is largely affected by central adaptations [160]), but may affect peripheral adaptations that are influenced by fuel availability such as the substrate usage and mitochondrial size, particularly in untrained participants. Although there is some potential for pre-exercise nutrition intake to influence adaptations to endurance training, the lack of research in endurance-trained subjects, the very large amounts of $\mathrm{CHO}$ ingested before exercise in some studies, and the provision of $\mathrm{CHO}$ both before and during exercise in other studies makes extrapolating results to trained athletes challenging. Additionally, some of the strongest evidence suggesting low-glycogen training can magnify signaling responses to exercise is based on studies performing the experimental exercise session a few hours after a glycogen-lowering exercise bout [149-151], and some of these effects might simply be attributable to performing two exercise sessions in close proximity [156].

Future training studies should compare fasted-state training against low-CHO and moderate-CHO pre-exercise meals, with both normal and low muscle glycogen, and in the context of both HIIT and steady-state continuous endurance training to determine if there are differential effects on fat oxidation and/or mitochondrial biogenesis. It would also be of interest to investigate if there is a threshold for the amount of pre-exercise CHO ingested, independent of muscle glycogen levels [161], above which adaptations may be negatively impacted but below which adaptations are not impaired. Additionally, sex-based differences in the response to training programs should be investigated, as females accounted for just $\sim 10 \%$ of participants in the training studies discussed.

\subsection{Performance Changes}

Studies comparing fed vs. fasted training have reported similar improvements in time-to-exhaustion during a maximal incremental test [145,162] and 1-h time-trial performance [145] following 6 weeks of endurance training. In contrast, time-to-fatigue at $85 \% \mathrm{VO}_{2} \mathrm{max}$ improved more in trained cyclists performing SIT in the fasted state compared to those that consumed $\mathrm{CHO}$ (>2.5 $\mathrm{g} \mathrm{kg}^{-1} \mathrm{CHO}$ prior and $\mathrm{CHO}$ drink during exercise), despite performing less work during training sessions [144]. Trained endurance athletes had greater improvements in a 12 min running time-trial following 3 weeks of aerobic training while consuming a low-GI compared with moderate GI diet [163].

Some studies comparing high vs. low glycogen training have reported similar performance improvements between groups [93,141,149,150,153], however greater improvements were seen following one and three weeks of sleep-low training [142,148], twice-daily training with low-CHO vs. high-CHO consumption between sessions [151], and twice- vs. once-daily training [35]. Two studies using a combination of tactics to vary $\mathrm{CHO}$ availability around training sessions (i.e., periodized-CHO) found similar improvements between chronic high- $\mathrm{CHO}$ and periodized-CHO diets, both of which resulted in greater improvements than a chronic low-CHO diet $[158,159]$. Future training studies should compare pre-exercise protein ingestion against $\mathrm{CHO}$-fed and fasted-state training in the context of both HIIT and steady-state continuous endurance training. Additionally, it would be of interest to study whether a delayed CHO ingestion strategy [164] in the context of low glycogen or fasted-state training has any influence on the adaptive response and whether it is training specific (e.g., high- vs. low-intensity training). 


\section{Science to Practice}

In an attempt to optimize both training adaptations and acute performance during key training sessions, current sport nutrition guidelines suggest training be performed both with high $\mathrm{CHO}$ availability, in order to enhance glycolytic and $\mathrm{CHO}$ oxidation pathways, and low $\mathrm{CHO}$ availability to increase the activation of acute cell signaling pathways related to mitochondrial biogenesis and fat oxidation [3]. Despite the rationale for a periodized approach to nutrition, whereby $\mathrm{CHO}$ availability for each workout is varied according to the type of session and its goals within a periodized training cycle [161], many athletes are not following these recommendations and/or are unclear on the current best-practice guidelines. For example, only $17-27 \%$ of elite athletes report following a periodized-CHO diet, and less than half of endurance athletes report varying their pre-exercise nutrition choices based on exercise duration or intensity $[16,165]$. Although training in the overnight-fasted state is performed by nearly two-thirds of endurance athletes $(63 \%)$, many are doing it because they think it is beneficial, while others avoid it because they think it is not beneficial [15]. Furthermore, nearly all beliefs and practices relating to pre-exercise nutrition appear to vary based on sex, competitive level, and habitual dietary pattern $[15,16]$. Taken together, this highlights the need for more research in trained athletes as well as improved communication of the available research to athletes and coaches. From the standpoint of practical application, the duration and intensity of the exercise session should be considered when considering the best pre-exercise nutrition choices, along with the personal preferences of each individual athlete, as described in Figure 9. While the principles behind these recommendations should be applicable to a broad population, the relative influence of nutrition on training adaptations may vary based on sex, BMI, and training status.

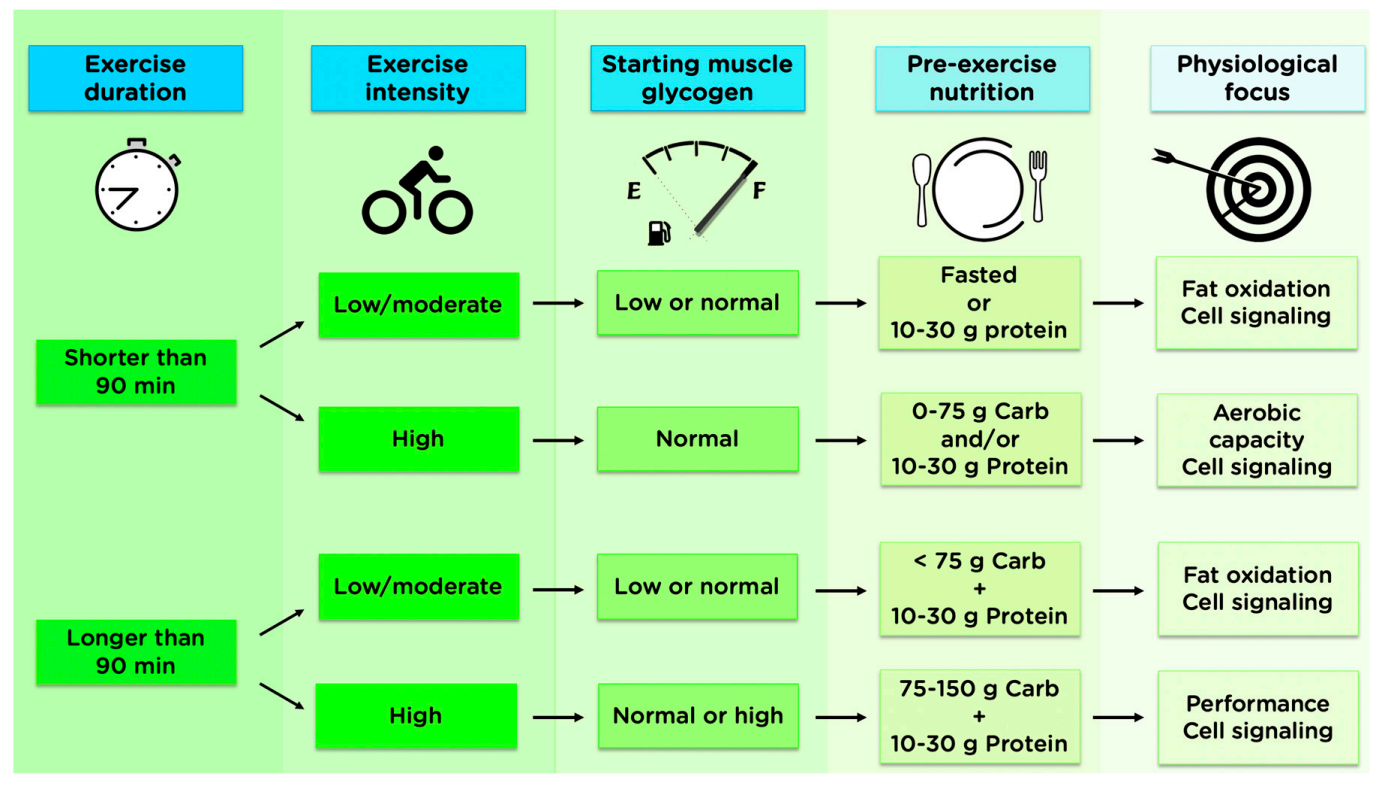

Figure 9. Practical application of pre-exercise nutrition to optimize training adaptations. The duration and intensity of the exercise session should be considered when considering the best pre-exercise nutrition choices. Before shorter duration exercise sessions that focus on lower intensity steady-state training, it may be beneficial to withhold $\mathrm{CHO}$, while there is little evidence supporting $\mathrm{CHO}$ restriction before high-intensity exercise. When consuming less than $\sim 75 \mathrm{~g} \mathrm{CHO}$, food choices before HIIT can be left to personal preference. For longer duration exercise ( $>90 \mathrm{~min}$ ), there is little evidence to suggest fasted-state training offers any additional benefit, although this is still practiced by approximately one-third of endurance athletes [16]. Ingesting less than $\sim 75 \mathrm{~g} \mathrm{CHO}$ is unlikely to impair mitochondrial signaling adaptations from longer-duration, low-intensity exercise, while consuming 75-150 g CHO prior to extended high-intensity exercise is suggested to increase endogenous fuel storage. 


\section{Conclusions and Practical Application}

The availability of endogenous and exogenous $\mathrm{CHO}$, fat, and protein before and during exercise can influence the acute and longer-term responses to endurance exercise. Acutely, $\mathrm{CHO}$ ingestion inhibits fat burning, however evidence showing enhanced fat burning capacity following long-term training in the fasted state is lacking. Contrasting findings related to the influence of $\mathrm{CHO}$ ingestion on mitochondrial signaling may be related to the amount of carbohydrate consumed and the intensity of exercise. Consumption of $>120 \mathrm{~g} \mathrm{CHO}$ before submaximal, steady-state exercise has blunted mitochondrial signaling, while $<70 \mathrm{~g} \mathrm{CHO}$ has not, yet $\mathrm{CHO}$ availability appears to have minimal effects following HIIT exercise. Performance is improved following pre-exercise $\mathrm{CHO}$ ingestion for longer but not shorter duration exercise, while training-induced performance changes following various pre-exercise nutrition strategies vary based on the type of nutrition protocol used. Caution should be used when generalizing these findings to wider populations, as the majority of research participants have been trained males between 20-30 years of age. In addition to wider participant demographics, more research is needed on the acute and longer-term effects of pre-exercise protein ingestion, studies in endurance-trained subjects performing fasted-state training compared with ingesting moderate and low-CHO meals before exercise, and fasted vs. fed-state training without $\mathrm{CHO}$ ingestion during exercise.

Supplementary Materials: The following are available online at http://www.mdpi.com/2072-6643/12/11/3473/s1, References for studies included in pooled analyses.

Author Contributions: Conceptualization, J.A.R., A.E.K., and D.J.P.; data curation, J.A.R.; writing—original draft preparation, J.A.R.; writing—review and editing, J.A.R., A.E.K., and D.J.P.; visualization, J.A.R. and D.J.P.; supervision, A.E.K. and D.J.P. All authors have read and agreed to the published version of the manuscript.

Funding: This research received no external funding.

Acknowledgments: The authors thank Tom Stewart for his technical assistance.

Conflicts of Interest: The authors declare no conflict of interest.

\section{References}

1. Seiler, $\mathrm{S}$. What is best practice for training intensity and duration distribution in endurance athletes? Int. J. Sports Physiol. Perform. 2010, 5, 276-291. [CrossRef] [PubMed]

2. Earnest, C.P.; Rothschild, J.; Harnish, C.R.; Naderi, A. Metabolic adaptations to endurance training and nutrition strategies influencing performance. Res. Sports Med. 2019, 27, 134-146. [CrossRef] [PubMed]

3. Stellingwerff, T.; Morton, J.P.; Burke, L.M. A Framework for Periodized Nutrition for Athletics. Int. J. Sport Nutr. Exerc. Metab. 2019, 29, 141-151. [CrossRef] [PubMed]

4. Tokmakidis, S.P.; Karamanolis, I.A. Effects of carbohydrate ingestion $15 \mathrm{~min}$ before exercise on endurance running capacity. Appl. Physiol. Nutr. Metab. 2008, 33, 441-449. [CrossRef]

5. Sherman, W.M.; Peden, M.C.; Wright, D.A. Carbohydrate feedings $1 \mathrm{~h}$ before exercise improves cycling performance. Am. J. Clin. Nutr. 1991, 54, 866-870. [CrossRef]

6. Hawley, J.A.; Morton, J.P. Ramping up the signal: Promoting endurance training adaptation in skeletal muscle by nutritional manipulation. Clin. Exp. Pharmacol. Physiol. 2014, 41, 608-613. [CrossRef]

7. Philp, A.; Burke, L.M.; Baar, K. Altering endogenous carbohydrate availability to support training adaptations. Nestle Nutr. Inst. Workshop Ser. 2011, 69, 19-31. [CrossRef]

8. Coffey, V.G.; Hawley, J.A. The molecular bases of training adaptation. Sports Med. 2007, 37, 737-763. [CrossRef]

9. Civitarese, A.E.; Hesselink, M.K.; Russell, A.P.; Ravussin, E.; Schrauwen, P. Glucose ingestion during exercise blunts exercise-induced gene expression of skeletal muscle fat oxidative genes. Am. J. Physiol. Endocrinol. Metab. 2005, 289, E1023-E1029. [CrossRef]

10. Edinburgh, R.M.; Hengist, A.; Smith, H.A.; Travers, R.L.; Koumanov, F.; Betts, J.A.; Thompson, D.; Walhin, J.P; Wallis, G.A.; Hamilton, D.L.; et al. Preexercise breakfast ingestion versus extended overnight fasting increases postprandial glucose flux after exercise in healthy men. Am. J. Physiol. Endocrinol. Metab. 2018, 315, E1062-E1074. [CrossRef] 
11. Lee-Young, R.S.; Palmer, M.J.; Linden, K.C.; LePlastrier, K.; Canny, B.J.; Hargreaves, M.; Wadley, G.D.; Kemp, B.E.; McConell, G.K. Carbohydrate ingestion does not alter skeletal muscle AMPK signaling during exercise in humans. Am. J. Physiol. Endocrinol. Metab. 2006, 291, E566-E573. [CrossRef] [PubMed]

12. Van Proeyen, K.; Szlufcik, K.; Nielens, H.; Pelgrim, K.; Deldicque, L.; Hesselink, M.; Van Veldhoven, P.; Hespel, P. Training in the fasted state improves glucose tolerance during fat-rich diet. J. Physiol. 2010, 588, 4289-4302. [CrossRef] [PubMed]

13. Stannard, S.R.; Buckley, A.J.; Edge, J.A.; Thompson, M.W. Adaptations to skeletal muscle with endurance exercise training in the acutely fed versus overnight-fasted state. J. Sci. Med. Sport 2010, 13, 465-469. [CrossRef] [PubMed]

14. De Bock, K.; Derave, W.; Eijnde, B.O.; Hesselink, M.K.; Koninckx, E.; Rose, A.J.; Schrauwen, P.; Bonen, A.; Richter, E.A.; Hespel, P. Effect of training in the fasted state on metabolic responses during exercise with carbohydrate intake. J. Appl. Physiol. (1985) 2008, 104, 1045-1055. [CrossRef]

15. Rothschild, J.A.; Kilding, A.E.; Plews, D.J. Prevalence and determinants of fasted training in endurance athletes: A survey analysis. Int. J. Sport Nutr. Exerc. Metab. 2020, 30, 345-356. [CrossRef]

16. Rothschild, J.; Kilding, A.E.; Plews, D.J. Pre-exercise nutrition habits and beliefs of endurance athletes vary by sex, competitive level and diet. J. Am. Coll. Nutr. 2020, in press. [CrossRef]

17. Wadley, G.D.; Nicolas, M.A.; Hiam, D.; McConell, G.K. Xanthine oxidase inhibition attenuates skeletal muscle signaling following acute exercise but does not impair mitochondrial adaptations to endurance training. Am. J. Physiol.-Endocrinol. Metab. 2013, 304, E853-E862. [CrossRef]

18. Cochran, A.J.; Percival, M.E.; Tricarico, S.; Little, J.P.; Cermak, N.; Gillen, J.B.; Tarnopolsky, M.A.; Gibala, M.J. Intermittent and continuous high-intensity exercise training induce similar acute but different chronic muscle adaptations. Exp. Physiol. 2014, 99, 782-791. [CrossRef]

19. Perry, C.G.; Lally, J.; Holloway, G.P.; Heigenhauser, G.J.; Bonen, A.; Spriet, L.L. Repeated transient mRNA bursts precede increases in transcriptional and mitochondrial proteins during training in human skeletal muscle. J. Physiol. 2010, 588, 4795-4810. [CrossRef]

20. Trefts, E.; Williams, A.S.; Wasserman, D.H. Exercise and the Regulation of Hepatic Metabolism. Prog. Mol. Biol. Transl. Sci. 2015, 135, 203-225. [CrossRef]

21. Nilsson, L.H.; Hultman, E. Liver glycogen in man-the effect of total starvation or a carbohydrate-poor diet followed by carbohydrate refeeding. Scand. J. Clin. Lab. Investig. 1973, 32, 325-330. [CrossRef] [PubMed]

22. Dohm, G.L.; Beeker, R.T.; Israel, R.G.; Tapscott, E.B. Metabolic responses to exercise after fasting. J. Appl. Physiol. 1986, 61, 1363-1368. [CrossRef] [PubMed]

23. Margolis, L.M.; Wilson, M.A.; Whitney, C.C.; Carrigan, C.T.; Murphy, N.E.; Hatch, A.M.; Montain, S.J.; Pasiakos, S.M. Exercising with low muscle glycogen content increases fat oxidation and decreases endogenous, but not exogenous carbohydrate oxidation. Metabolism 2019, 97, 1-8. [CrossRef] [PubMed]

24. Coggan, A.R.; Coyle, E.F. Carbohydrate ingestion during prolonged exercise: Effects on metabolism and performance. Exerc. Sport Sci. Rev. 1991, 19, 1-40. [CrossRef]

25. Vieira, A.F.; Costa, R.R.; Macedo, R.C.O.; Coconcelli, L.; Kruel, L.F.M. Effects of aerobic exercise performed in fasted v. fed state on fat and carbohydrate metabolism in adults: A systematic review and meta-analysis. Br. J. Nutr. 2016, 116, 1153-1164. [CrossRef]

26. Andersson Hall, U.; Edin, F.; Pedersen, A.; Madsen, K. Whole-body fat oxidation increases more by prior exercise than overnight fasting in elite endurance athletes. Appl. Physiol. Nutr. Metab. 2015, 41, 430-437. [CrossRef] [PubMed]

27. Marmy-Conus, N.; Fabris, S.; Proietto, J.; Hargreaves, M. Preexercise glucose ingestion and glucose kinetics during exercise. J. Appl. Physiol. 1996, 81, 853-857. [CrossRef]

28. Horowitz, J.F.; Mora-Rodriguez, R.; Byerley, L.O.; Coyle, E.F. Lipolytic suppression following carbohydrate ingestion limits fat oxidation during exercise. Am. J. Physiol. 1997, 273, E768-E775. [CrossRef] [PubMed]

29. Coyle, E.F.; Jeukendrup, A.E.; Wagenmakers, A.; Saris, W. Fatty acid oxidation is directly regulated by carbohydrate metabolism during exercise. Am. J. Physiol.-Endocrinol. Metab. 1997, 273, E268-E275. [CrossRef]

30. De Bock, K.; Richter, E.A.; Russell, A.; Eijnde, B.O.; Derave, W.; Ramaekers, M.; Koninckx, E.; Leger, B.; Verhaeghe, J.; Hespel, P. Exercise in the fasted state facilitates fibre type-specific intramyocellular lipid breakdown and stimulates glycogen resynthesis in humans. J. Physiol. 2005, 564, 649-660. [CrossRef]

31. Edinburgh, R.M.; Bradley, H.E.; Abdullah, N.-F.; Robinson, S.L.; Chrzanowski-Smith, O.J.; Walhin, J.-P.; Joanisse, S.; Manolopoulos, K.N.; Philp, A.; Hengist, A.; et al. Lipid metabolism links nutrient-exercise timing to insulin sensitivity in men classified as overweight or obese. J. Clin. Endocrinol. Metab. 2020, 105, 660-676. [CrossRef] 
32. Van Loon, L.J.; Koopman, R.; Stegen, J.H.; Wagenmakers, A.J.; Keizer, H.A.; Saris, W.H. Intramyocellular lipids form an important substrate source during moderate intensity exercise in endurance-trained males in a fasted state. J. Physiol. 2003, 553, 611-625. [CrossRef]

33. Montain, S.J.; Hopper, M.; Coggan, A.R.; Coyle, E.F. Exercise metabolism at different time intervals after a meal. J. Appl. Physiol. 1991, 70, 882-888. [CrossRef] [PubMed]

34. Knapik, J.J.; Meredith, C.N.; Jones, B.H.; Suek, L.; Young, V.R.; Evans, W.J. Influence of fasting on carbohydrate and fat metabolism during rest and exercise in men. J. Appl. Physiol. (1985) 1988, 64, 1923-1929. [CrossRef] [PubMed]

35. Hansen, A.K.; Fischer, C.P.; Plomgaard, P.; Andersen, J.L.; Saltin, B.; Pedersen, B.K. Skeletal muscle adaptation: Training twice every second day vs. training once daily. J. Appl. Physiol. 2005, 98, 93-99. [CrossRef] [PubMed]

36. Bartlett, J.D.; Louhelainen, J.; Iqbal, Z.; Cochran, A.J.; Gibala, M.J.; Gregson, W.; Close, G.L.; Drust, B.; Morton, J.P. Reduced carbohydrate availability enhances exercise-induced p53 signaling in human skeletal muscle: Implications for mitochondrial biogenesis. Am. J. Physiol. Regul. Integr. Comp. Physiol. 2013, 304, R450-R458. [CrossRef] [PubMed]

37. Gillen, J.B.; West, D.W.D.; Williamson, E.P.; Fung, H.J.W.; Moore, D.R. Low-Carbohydrate Training Increases Protein Requirements of Endurance Athletes. Med. Sci. Sports Exerc. 2019, 51, 2294-2301. [CrossRef]

38. Howarth, K.R.; Phillips, S.M.; MacDonald, M.J.; Richards, D.; Moreau, N.A.; Gibala, M.J. Effect of glycogen availability on human skeletal muscle protein turnover during exercise and recovery. J. Appl. Physiol. (1985) 2010, 109, 431-438. [CrossRef]

39. Lemon, P.W.; Mullin, J.P. Effect of initial muscle glycogen levels on protein catabolism during exercise. J. Appl. Physiol. Respir. Environ. Exerc. Physiol. 1980, 48, 624-629. [CrossRef]

40. Weltan, S.M.; Bosch, A.N.; Dennis, S.C.; Noakes, T.D. Preexercise muscle glycogen content affects metabolism during exercise despite maintenance of hyperglycemia. Am. J. Physiol. 1998, 274, E83-E88. [CrossRef]

41. Hargreaves, M.; McConell, G.; Proietto, J. Influence of muscle glycogen on glycogenolysis and glucose uptake during exercise in humans. J. Appl. Physiol. 1995, 78, 288-292. [CrossRef] [PubMed]

42. Devlin, J.T.; Calles-Escandon, J.; Horton, E.S. Effects of preexercise snack feeding on endurance cycle exercise. J. Appl. Physiol. 1986, 60, 980-985. [CrossRef] [PubMed]

43. Neufer, P.D.; Costill, D.L.; Flynn, M.G.; Kirwan, J.P.; Mitchell, J.B.; Houmard, J. Improvements in exercise performance: Effects of carbohydrate feedings and diet. J. Appl. Physiol. 1987, 62, 983-988. [CrossRef] [PubMed]

44. Febbraio, M.A.; Stewart, K.L. CHO feeding before prolonged exercise: Effect of glycemic index on muscle glycogenolysis and exercise performance. J. Appl. Physiol. 1996, 81, 1115-1120. [CrossRef] [PubMed]

45. Tsintzas, K.; Williams, C. Human muscle glycogen metabolism during exercise. Effect of carbohydrate supplementation. Sports Med. 1998, 25, 7-23. [CrossRef] [PubMed]

46. Impey, S.G.; Smith, D.; Robinson, A.L.; Owens, D.J.; Bartlett, J.D.; Smith, K.; Limb, M.; Tang, J.; Fraser, W.D.; Close, G.L. Leucine-enriched protein feeding does not impair exercise-induced free fatty acid availability and lipid oxidation: Beneficial implications for training in carbohydrate-restricted states. Amino Acids 2015, 47, 407-416. [CrossRef]

47. Taylor, C.; Bartlett, J.D.; van de Graaf, C.S.; Louhelainen, J.; Coyne, V.; Iqbal, Z.; MacLaren, D.P.; Gregson, W.; Close, G.L.; Morton, J.P. Protein ingestion does not impair exercise-induced AMPK signalling when in a glycogen-depleted state: Implications for train-low compete-high. Eur. J. Appl. Physiol. 2013, 113, 1457-1468. [CrossRef]

48. Enevoldsen, L.; Simonsen, L.; Macdonald, I.; Bülow, J. The combined effects of exercise and food intake on adipose tissue and splanchnic metabolism. J. Physiol. 2004, 561, 871-882. [CrossRef]

49. Larsen, M.S.; Holm, L.; Svart, M.V.; Hjelholt, A.J.; Bengtsen, M.B.; Dollerup, O.L.; Dalgaard, L.B.; Vendelbo, M.H.; van Hall, G.; Moller, N.; et al. Effects of protein intake prior to carbohydrate-restricted endurance exercise: A randomized crossover trial. J. Int. Soc. Sports Nutr. 2020, 17, 7. [CrossRef]

50. Wright, D.; Sherman, W.; Dernbach, A. Carbohydrate feedings before, during, or in combination improve cycling endurance performance. J. Appl. Physiol. 1991, 71, 1082-1088. [CrossRef]

51. Romijn, J.A.; Coyle, E.F.; Sidossis, L.S.; Gastaldelli, A.; Horowitz, J.F.; Endert, E.; Wolfe, R.R. Regulation of endogenous fat and carbohydrate metabolism in relation to exercise intensity and duration. Am. J. Physiol. 1993, 265, E380-E391. [CrossRef] 
52. Sherman, W.M.; Brodowicz, G.; Wright, D.A.; Allen, W.K.; Simonsen, J.; Dernbach, A. Effects of 4 h preexercise carbohydrate feedings on cycling performance. Med. Sci. Sports Exerc. 1989, 21, 598-604. [CrossRef] [PubMed]

53. Jentjens, R.L.; Cale, C.; Gutch, C.; Jeukendrup, A.E. Effects of pre-exercise ingestion of differing amounts of carbohydrate on subsequent metabolism and cycling performance. Eur. J. Appl. Physiol. 2003, 88, 444-452. [CrossRef] [PubMed]

54. Calles-Escandón, J.; Devlin, J.T.; Whitcomb, W.; Horton, E.S. Pre-exercise feeding does not affect endurance cycle exercise but attenuates post-exercise starvation-like response. Med. Sci. Sports Exerc. 1991, 23, 818-824. [PubMed]

55. Cramp, T.; Broad, E.; Martin, D.; Meyer, B.J. Effects of preexercise carbohydrate ingestion on mountain bike performance. Med. Sci. Sports Exerc. 2004, 36, 1602-1609. [CrossRef] [PubMed]

56. Khong, T.K.; Selvanayagam, V.S.; Hamzah, S.H.; Yusof, A. Effect of quantity and quality of pre-exercise carbohydrate meals on central fatigue. J. Appl. Physiol. 2018, 125, 1021-1029. [CrossRef]

57. Okano, G.; Sato, Y.; Takumi, Y.; Sugawara, M. Effect of 4 h preexercise high carbohydrate and high fat meal ingestion on endurance performance and metabolism. Int. J. Sports Med. 1996, 17, 530-534. [CrossRef]

58. Smith, G.J.; Rhodes, E.C.; Langill, R.H. The effect of pre-exercise glucose ingestion on performance during prolonged swimming. Int. J. Sport Nutr. Exerc. Metab. 2002, 12, 136-144. [CrossRef]

59. Coyle, E.F.; Coggan, A.R.; Hemmert, M.K.; Lowe, R.C.; Walters, T.J. Substrate usage during prolonged exercise following a preexercise meal. J. Appl. Physiol. 1985, 59, 429-433. [CrossRef]

60. Whitley, H.A.; Humphreys, S.M.; Campbell, I.T.; Keegan, M.A.; Jayanetti, T.D.; Sperry, D.A.; MacLaren, D.P.; Reilly, T.; Frayn, K.N. Metabolic and performance responses during endurance exercise after high-fat and high-carbohydrate meals. J. Appl. Physiol. 1998, 85, 418-424. [CrossRef]

61. Moseley, L.; Lancaster, G.I.; Jeukendrup, A.E. Effects of timing of pre-exercise ingestion of carbohydrate on subsequent metabolism and cycling performance. Eur. J. Appl. Physiol. 2003, 88, 453-458. [CrossRef] [PubMed]

62. Willcutts, K.F.; Wilcox, A.; Grunewald, K. Energy metabolism during exercise at different time intervals following a meal. Int. J. Sports Med. 1988, 9, 240-243. [CrossRef] [PubMed]

63. Wismann, J.; Willoughby, D. Gender differences in carbohydrate metabolism and carbohydrate loading. J. Int. Soc. Sports Nutr. 2006, 3, 28-34. [CrossRef] [PubMed]

64. Ashley, C.D.; Kramer, M.L.; Bishop, P. Estrogen and substrate metabolism: A review of contradictory research. Sports Med. 2000, 29, 221-227. [CrossRef]

65. Sims, S.T.; Heather, A.K. Myths and Methodologies: Reducing scientific design ambiguity in studies comparing sexes and/or menstrual cycle phases. Exp. Physiol. 2018, 103, 1309-1317. [CrossRef]

66. Aird, T.P.; Davies, R.W.; Carson, B.P. Effects of fasted vs. fed state exercise on performance and post-exercise metabolism: A systematic review \& meta-analysis. Scand. J. Med. Sci. Sports 2018, 28, 1476-1493.

67. Galloway, S.D.; Lott, M.J.; Toulouse, L.C. Preexercise carbohydrate feeding and high-intensity exercise capacity: Effects of timing of intake and carbohydrate concentration. Int. J. Sport Nutr. Exerc. Metab. 2014, 24, 258-266. [CrossRef]

68. Little, J.P.; Chilibeck, P.D.; Ciona, D.; Forbes, S.; Rees, H.; Vandenberg, A.; Zello, G.A. Effect of low- and high-glycemic-index meals on metabolism and performance during high-intensity, intermittent exercise. Int. J. Sport Nutr. Exerc. Metab. 2010, 20, 447-456. [CrossRef]

69. Scott, J.P.; Sale, C.; Greeves, J.P.; Casey, A.; Dutton, J.; Fraser, W.D. Effect of fasting versus feeding on the bone metabolic response to running. Bone 2012, 51, 990-999. [CrossRef]

70. Hetlelid, K.J.; Plews, D.J.; Herold, E.; Laursen, P.B.; Seiler, S. Rethinking the role of fat oxidation: Substrate utilisation during high-intensity interval training in well-trained and recreationally trained runners. BMJOpen Sport Exerc. Med. 2015, 1, e000047. [CrossRef]

71. Tenforde, A.S.; Barrack, M.T.; Nattiv, A.; Fredericson, M. Parallels with the Female Athlete Triad in Male Athletes. Sports Med. 2016, 46, 171-182. [CrossRef] [PubMed]

72. Wilson, P.B. 'I think I'm gonna hurl': A Narrative Review of the Causes of Nausea and Vomiting in Sport. Sports 2019, 7, 162. [CrossRef] [PubMed]

73. De Oliveira, E.P.; Burini, R.C.; Jeukendrup, A. Gastrointestinal complaints during exercise: Prevalence, etiology, and nutritional recommendations. Sports Med. 2014, 44 (Suppl. 1), S79-S85. [CrossRef] [PubMed] 
74. Egan, B.; Zierath, J.R. Exercise metabolism and the molecular regulation of skeletal muscle adaptation. Cell Metab. 2013, 17, 162-184. [CrossRef] [PubMed]

75. Hardie, D.G.; Ross, F.A.; Hawley, S.A. AMPK: A nutrient and energy sensor that maintains energy homeostasis. Nat. Rev. Mol. Cell Biol. 2012, 13, 251-262. [CrossRef] [PubMed]

76. Steinberg, G.R.; Kemp, B.E. AMPK in Health and Disease. Physiol. Rev. 2009, 89, 1025-1078. [CrossRef]

77. Wojtaszewski, J.F.; Nielsen, P.; Hansen, B.F.; Richter, E.A.; Kiens, B. Isoform-specific and exercise intensity-dependent activation of 5'-AMP-activated protein kinase in human skeletal muscle. J. Physiol. 2000, 528, 221-226. [CrossRef]

78. McConell, G.K.; Wadley, G.D.; Le Plastrier, K.; Linden, K.C. Skeletal muscle AMPK is not activated during $2 \mathrm{~h}$ of moderate intensity exercise at 65\% VO2 peak in endurance trained men. J. Physiol. 2020, 598, 3859-3870. [CrossRef]

79. Janzen, N.R.; Whitfield, J.; Hoffman, N.J. Interactive Roles for AMPK and Glycogen from Cellular Energy Sensing to Exercise Metabolism. Int. J. Mol. Sci. 2018, 19, 3344. [CrossRef]

80. Bartlett, J.D.; Hawley, J.A.; Morton, J.P. Carbohydrate availability and exercise training adaptation: Too much of a good thing? Eur. J. Sport Sci. 2015, 15, 3-12. [CrossRef]

81. Akerstrom, T.C.; Birk, J.B.; Klein, D.K.; Erikstrup, C.; Plomgaard, P.; Pedersen, B.K.; Wojtaszewski, J. Oral glucose ingestion attenuates exercise-induced activation of $5^{\prime}$-AMP-activated protein kinase in human skeletal muscle. Biochem. Biophys. Res. Commun. 2006, 342, 949-955. [CrossRef]

82. Treebak, J.T.; Pehmoller, C.; Kristensen, J.M.; Kjobsted, R.; Birk, J.B.; Schjerling, P.; Richter, E.A.; Goodyear, L.J.; Wojtaszewski, J.F. Acute exercise and physiological insulin induce distinct phosphorylation signatures on TBC1D1 and TBC1D4 proteins in human skeletal muscle. J. Physiol. 2014, 592, 351-375. [CrossRef]

83. Roepstorff, C.; Halberg, N.; Hillig, T.; Saha, A.K.; Ruderman, N.B.; Wojtaszewski, J.F.; Richter, E.A.; Kiens, B. Malonyl-CoA and carnitine in regulation of fat oxidation in human skeletal muscle during exercise. Am. J. Physiol. Endocrinol. Metab. 2005, 288, E133-E142. [CrossRef]

84. Steinberg, G.R.; Watt, M.J.; McGee, S.L.; Chan, S.; Hargreaves, M.; Febbraio, M.A.; Stapleton, D.; Kemp, B.E. Reduced glycogen availability is associated with increased AMPK $\alpha 2$ activity, nuclear AMPK $\alpha 2$ protein abundance, and GLUT4 mRNA expression in contracting human skeletal muscle. Appl. Physiol. Nutr. Metab. 2006, 31, 302-312. [CrossRef]

85. Wojtaszewski, J.F.; MacDonald, C.; Nielsen, J.N.; Hellsten, Y.; Hardie, D.G.; Kemp, B.E.; Kiens, B.; Richter, E.A. Regulation of $5^{\prime}$ AMP-activated protein kinase activity and substrate utilization in exercising human skeletal muscle. Am. J. Physiol. Endocrinol. Metab. 2003, 284, E813-E822. [CrossRef]

86. Impey, S.G.; Hammond, K.M.; Shepherd, S.O.; Sharples, A.P.; Stewart, C.; Limb, M.; Smith, K.; Philp, A.; Jeromson, S.; Hamilton, D.L.; et al. Fuel for the work required: A practical approach to amalgamating train-low paradigms for endurance athletes. Physiol. Rep. 2016, 4. [CrossRef]

87. Hearris, M.A.; Hammond, K.M.; Seaborne, R.A.; Stocks, B.; Shepherd, S.O.; Philp, A.; Sharples, A.P.; Morton, J.P.; Louis, J.B. Graded reductions in preexercise muscle glycogen impair exercise capacity but do not augment skeletal muscle cell signaling: Implications for CHO periodization. J. Appl. Physiol. 2019, 126, 1587-1597. [CrossRef]

88. Hearris, M.A.; Owens, D.J.; Strauss, J.A.; Shepherd, S.O.; Sharples, A.P.; Morton, J.P.; Louis, J.B. Graded reductions in pre-exercise glycogen concentration do not augment exercise-induced nuclear AMPK and PGC-1 $\alpha$ protein content in human muscle. Exp. Physiol. 2020. in Press. [CrossRef]

89. Stocks, B.; Dent, J.R.; Ogden, H.B.; Zemp, M.; Philp, A. Postexercise skeletal muscle signaling responses to moderate- to high-intensity steady-state exercise in the fed or fasted state. Am. J. Physiol. Endocrinol. Metab. 2019, 316, E230-E238. [CrossRef]

90. McConell, G.K.; Lee-Young, R.S.; Chen, Z.P.; Stepto, N.K.; Huynh, N.N.; Stephens, T.J.; Canny, B.J.; Kemp, B.E. Short-term exercise training in humans reduces AMPK signalling during prolonged exercise independent of muscle glycogen. J. Physiol. 2005, 568, 665-676. [CrossRef]

91. Mortensen, B.; Hingst, J.R.; Frederiksen, N.; Hansen, R.W.; Christiansen, C.S.; Iversen, N.; Friedrichsen, M.; Birk, J.B.; Pilegaard, H.; Hellsten, Y.; et al. Effect of birth weight and 12 weeks of exercise training on exercise-induced AMPK signaling in human skeletal muscle. Am. J. Physiol. Endocrinol. Metab. 2013, 304, E1379-E1390. [CrossRef] [PubMed] 
92. Guerra, B.; Guadalupe-Grau, A.; Fuentes, T.; Ponce-Gonzalez, J.G.; Morales-Alamo, D.; Olmedillas, H.; Guillen-Salgado, J.; Santana, A.; Calbet, J.A. SIRT1, AMP-activated protein kinase phosphorylation and downstream kinases in response to a single bout of sprint exercise: Influence of glucose ingestion. Eur. J. Appl. Physiol. 2010, 109, 731-743. [CrossRef] [PubMed]

93. Morton, J.P.; Croft, L.; Bartlett, J.D.; MacLaren, D.P.; Reilly, T.; Evans, L.; McArdle, A.; Drust, B. Reduced carbohydrate availability does not modulate training-induced heat shock protein adaptations but does upregulate oxidative enzyme activity in human skeletal muscle. J. Appl. Physiol. 2009, 106, 1513-1521. [CrossRef] [PubMed]

94. Akerstrom, T.C.; Fischer, C.P.; Plomgaard, P.; Thomsen, C.; Van Hall, G.; Pedersen, B.K. Glucose ingestion during endurance training does not alter adaptation. J. Appl. Physiol. 2009, 106, 1771-1779. [CrossRef]

95. Islam, H.; Edgett, B.A.; Bonafiglia, J.T.; Shulman, T.; Ma, A.; Quadrilatero, J.; Simpson, C.A.; Gurd, B.J. Repeatability of exercise-induced changes in mRNA expression and technical considerations for qPCR analysis in human skeletal muscle. Exp. Physiol. 2019, 104, 407-420. [CrossRef]

96. Chin, E.R. The role of calcium and calcium/calmodulin-dependent kinases in skeletal muscle plasticity and mitochondrial biogenesis. Proc. Nutr. Soc. 2004, 63, 279-286. [CrossRef]

97. Wright, D.C. Mechanisms of calcium-induced mitochondrial biogenesis and GLUT4 synthesis. Appl. Physiol. Nutr. Metab. 2007, 32, 840-845. [CrossRef]

98. Margolis, L.M.; Pasiakos, S.M. Optimizing intramuscular adaptations to aerobic exercise: Effects of carbohydrate restriction and protein supplementation on mitochondrial biogenesis. Adv. Nutr. 2013, 4, 657-664. [CrossRef]

99. Jordy, A.B.; Kiens, B. Regulation of exercise-induced lipid metabolism in skeletal muscle. Exp. Physiol. 2014, 99, 1586-1592. [CrossRef]

100. Yeo, W.K.; McGee, S.L.; Carey, A.L.; Paton, C.D.; Garnham, A.P.; Hargreaves, M.; Hawley, J.A. Acute signalling responses to intense endurance training commenced with low or normal muscle glycogen. Exp. Physiol. 2010, 95, 351-358. [CrossRef]

101. Cochran, A.J.; Little, J.P.; Tarnopolsky, M.A.; Gibala, M.J. Carbohydrate feeding during recovery alters the skeletal muscle metabolic response to repeated sessions of high-intensity interval exercise in humans. J. Appl. Physiol. 2010, 108, 628-636. [CrossRef] [PubMed]

102. Chan, M.S.; McGee, S.L.; Watt, M.J.; Hargreaves, M.; Febbraio, M.A. Altering dietary nutrient intake that reduces glycogen content leads to phosphorylation of nuclear p38 MAP kinase in human skeletal muscle: Association with IL-6 gene transcription during contraction. FASEB J. 2004, 18, 1785-1787. [CrossRef] [PubMed]

103. Zbinden-Foncea, H.; Van Loon, L.J.; Raymackers, J.-M.; Francaux, M.; Deldicque, L. Contribution of nonesterified fatty acids to mitogen-activated protein kinase activation in human skeletal muscle during endurance exercise. Int. J. Sport Nutr. Exerc. Metab. 2013, 23, 201-209. [CrossRef] [PubMed]

104. Garcia-Roves, P.; Huss, J.M.; Han, D.H.; Hancock, C.R.; Iglesias-Gutierrez, E.; Chen, M.; Holloszy, J.O. Raising plasma fatty acid concentration induces increased biogenesis of mitochondria in skeletal muscle. Proc. Natl. Acad. Sci. USA 2007, 104, 10709-10713. [CrossRef]

105. Fritzen, A.M.; Lundsgaard, A.M.; Kiens, B. Tuning fatty acid oxidation in skeletal muscle with dietary fat and exercise. Nat. Rev. Endocrinol. 2020, 16, 683-696. [CrossRef]

106. Gleeson, M.; Maughan, R.J.; Greenhaff, P.L. Comparison of the effects of pre-exercise feeding of glucose, glycerol and placebo on endurance and fuel homeostasis in man. Eur. J. Appl. Physiol. Occup. Physiol. 1986, 55, 645-653. [CrossRef]

107. Foster, C.; Costill, D.; Fink, W. Effects of preexercise feedings on endurance performance. Med. Sci. Sports 1979, 11, 1-5.

108. Febbraio, M.A.; Chiu, A.; Angus, D.J.; Arkinstall, M.J.; Hawley, J.A. Effects of carbohydrate ingestion before and during exercise on glucose kinetics and performance. J. Appl. Physiol. 2000, 89, 2220-2226. [CrossRef]

109. Paul, D.; Jacobs, K.A.; Geor, R.J.; Hinchcliff, K.W. No effect of pre-exercise meal on substrate metabolism and time trial performance during intense endurance exercise. Int. J. Sport Nutr. Exerc. Metab. 2003, 13, 489-503. [CrossRef]

110. Margaritelis, N.V.; Paschalis, V.; Theodorou, A.A.; Kyparos, A.; Nikolaidis, M.G. Redox basis of exercise physiology. Redox Biol. 2020, 35, 101499. [CrossRef] 
111. Gregersen, S.; Samocha-Bonet, D.; Heilbronn, L.K.; Campbell, L.V. Inflammatory and oxidative stress responses to high-carbohydrate and high-fat meals in healthy humans. J. Nutr. Metab. 2012, 2012, 238056. [CrossRef]

112. Margaritelis, N.V.; Theodorou, A.A.; Paschalis, V.; Veskoukis, A.S.; Dipla, K.; Zafeiridis, A.; Panayiotou, G.; Vrabas, I.S.; Kyparos, A.; Nikolaidis, M.G. Adaptations to endurance training depend on exercise-induced oxidative stress: Exploiting redox interindividual variability. Acta Physiol. 2018, 222, e12898. [CrossRef] [PubMed]

113. Henriquez-Olguin, C.; Renani, L.B.; Arab-Ceschia, L.; Raun, S.H.; Bhatia, A.; Li, Z.; Knudsen, J.R.; Holmdahl, R.; Jensen, T.E. Adaptations to high-intensity interval training in skeletal muscle require NADPH oxidase 2. Redox Biol. 2019, 24, 101188. [CrossRef] [PubMed]

114. Carnevale, R.; Pignatelli, P.; Nocella, C.; Loffredo, L.; Pastori, D.; Vicario, T.; Petruccioli, A.; Bartimoccia, S.; Violi, F. Extra virgin olive oil blunt post-prandial oxidative stress via NOX2 down-regulation. Atherosclerosis 2014, 235, 649-658. [CrossRef] [PubMed]

115. Nieman, D.C.; Gillitt, N.D.; Chen, G.-Y.; Zhang, Q.; Sha, W.; Kay, C.D.; Chandra, P.; Kay, K.L.; Lila, M.A. Blueberry and/or Banana Consumption Mitigate Arachidonic, Cytochrome P450 Oxylipin Generation During Recovery From 75-Km Cycling: A Randomized Trial. Front. Nutr. 2020, 7, 121. [CrossRef] [PubMed]

116. Chen, X.; Jia, G.; Liu, G.; Zhao, H.; Huang, Z. Effects of apple polyphenols on myofiber-type transformation in longissimus dorsi muscle of finishing pigs. Anim. Biotechnol. 2020, 1-8. [CrossRef] [PubMed]

117. Draganidis, D.; Karagounis, L.G.; Athanailidis, I.; Chatzinikolaou, A.; Jamurtas, A.Z.; Fatouros, I.G. Inflammaging and skeletal muscle: Can protein intake make a difference? J. Nutr. 2016, 146, 1940-1952. [CrossRef]

118. Cluberton, L.J.; McGee, S.L.; Murphy, R.M.; Hargreaves, M. Effect of carbohydrate ingestion on exercise-induced alterations in metabolic gene expression. J. Appl. Physiol. 2005, 99, 1359-1363. [CrossRef]

119. Akerstrom, T.C.; Krogh-Madsen, R.; Petersen, A.M.; Pedersen, B.K. Glucose ingestion during endurance training in men attenuates expression of myokine receptor. Exp. Physiol. 2009, 94, 1124-1131. [CrossRef]

120. Spencer, M.K.; Yan, Z.; Katz, A. Carbohydrate supplementation attenuates IMP accumulation in human muscle during prolonged exercise. Am. J. Physiol. 1991, 261, C71-C76. [CrossRef]

121. Laursen, P.B. Training for intense exercise performance: High-intensity or high-volume training? Scand. J. Med. Sci. Sports 2010, 20 (Suppl. 2), 1-10. [CrossRef] [PubMed]

122. Combes, A.; Dekerle, J.; Webborn, N.; Watt, P.; Bougault, V.; Daussin, F.N. Exercise-induced metabolic fluctuations influence AMPK, p38-MAPK and CaMKII phosphorylation in human skeletal muscle. Physiol. Rep. 2015, 3, e12462. [CrossRef] [PubMed]

123. Chryssanthopoulos, C.; Williams, C.; Wilson, W.; Asher, L.; Hearne, L. Comparison between carbohydrate feedings before and during exercise on running performance during a 30-km treadmill time trial. Int. J. Sport Nutr. Exerc. Metab. 1994, 4, 374-386. [CrossRef] [PubMed]

124. Burke, L.M.; Claassen, A.; Hawley, J.A.; Noakes, T.D. Carbohydrate intake during prolonged cycling minimizes effect of glycemic index of preexercise meal. J. Appl. Physiol. 1998, 85, 2220-2226. [CrossRef] [PubMed]

125. Rowlands, D.S.; Hopkins, W.G. Effect of high-fat, high-carbohydrate, and high-protein meals on metabolism and performance during endurance cycling. Int. J. Sport Nutr. Exerc. Metab. 2002, 12, 318-335. [CrossRef]

126. Learsi, S.K.; Ghiarone, T.; Silva-Cavalcante, M.D.; Andrade-Souza, V.A.; Ataide-Silva, T.; Bertuzzi, R.; de Araujo, G.G.; McConell, G.; Lima-Silva, A.E. Cycling time trial performance is improved by carbohydrate ingestion during exercise regardless of a fed or fasted state. Scand. J. Med. Sci. Sports 2019, 29, 651-662. [CrossRef]

127. Little, J.P.; Chilibeck, P.D.; Ciona, D.; Vandenberg, A.; Zello, G.A. The effects of low- and high-glycemic index foods on high-intensity intermittent exercise. Int. J. Sports Physiol. Perform. 2009, 4, 367-380. [CrossRef]

128. Coffey, V.G.; Moore, D.R.; Burd, N.A.; Rerecich, T.; Stellingwerff, T.; Garnham, A.P.; Phillips, S.M.; Hawley, J.A. Nutrient provision increases signalling and protein synthesis in human skeletal muscle after repeated sprints. Eur. J. Appl. Physiol. 2011, 111, 1473-1483. [CrossRef]

129. Pritchett, K.; Bishop, P.; Pritchett, R.; Kovacs, M.; Davis, J.; Casaru, C.; Green, M. Effects of timing of pre-exercise nutrient intake on glucose responses and intermittent cycling performance. S. Afr. J. Sports Med. 2008, 20, 86-90. [CrossRef] 
130. Astorino, T.A.; Sherrick, S.; Mariscal, M.; Jimenez, V.C.; Stetson, K.; Courtney, D. No effect of meal intake on physiological or perceptual responses to self-selected high intensity interval exercise (HIIE). Biol. Sport 2019, 36, 225. [CrossRef]

131. Murakami, I.; Sakuragi, T.; Uemura, H.; Menda, H.; Shindo, M.; Tanaka, H. Significant effect of a pre-exercise high-fat meal after a 3-day high-carbohydrate diet on endurance performance. Nutrients 2012, 4, 625-637. [CrossRef] [PubMed]

132. Burdon, C.A.; Spronk, I.; Cheng, H.L.; O'Connor, H.T. Effect of Glycemic Index of a Pre-exercise Meal on Endurance Exercise Performance: A Systematic Review and Meta-analysis. Sports Med. 2017, 47, 1087-1101. [CrossRef] [PubMed]

133. Kern, M.; Heslin, C.J.; Rezende, R.S. Metabolic and performance effects of raisins versus sports gel as pre-exercise feedings in cyclists. J. Strength Cond. Res. 2007, 21, 1204-1207. [PubMed]

134. Campbell, C.; Prince, D.; Braun, M.; Applegate, E.; Casazza, G.A. Carbohydrate-supplement form and exercise performance. Int. J. Sport Nutr. Exerc. Metab. 2008, 18, 179-190. [CrossRef] [PubMed]

135. Cramer, M.J.; Dumke, C.L.; Hailes, W.S.; Cuddy, J.S.; Ruby, B.C. Postexercise Glycogen Recovery and Exercise Performance is Not Significantly Different Between Fast Food and Sport Supplements. Int. J. Sport Nutr. Exerc. Metab. 2015, 25, 448-455. [CrossRef]

136. Jeukendrup, A.E.; Killer, S.C. The myths surrounding pre-exercise carbohydrate feeding. Ann. Nutr. Metab. 2010, 57 (Suppl. 2), 18-25. [CrossRef]

137. Mears, S.A.; Dickinson, K.; Bergin-Taylor, K.; Dee, R.; Kay, J.; James, L.J. Perception of Breakfast Ingestion Enhances High-Intensity Cycling Performance. Int. J. Sports Physiol. Perform. 2018, 13, 504-509. [CrossRef]

138. Clark, V.R.; Hopkins, W.G.; Hawley, J.A.; Burke, L.M. Placebo effect of carbohydrate feedings during a 40-km cycling time trial. Med. Sci. Sports Exerc. 2000, 32, 1642-1647. [CrossRef]

139. Hulston, C.J.; Jeukendrup, A.E. No placebo effect from carbohydrate intake during prolonged exercise. Int. J. Sport Nutr. Exerc. Metab. 2009, 19, 275-284. [CrossRef]

140. Waterworth, S.P.; Spencer, C.C.; Porter, A.L.; Morton, J.P. Perception of Carbohydrate Availability Augments High-Intensity Intermittent Exercise Capacity Under Sleep-Low, Train-Low Conditions. Int. J. Sport Nutr. Exerc. Metab. 2020, 30, 105-111. [CrossRef]

141. Riis, S.; Moller, A.B.; Dollerup, O.; Hoffner, L.; Jessen, N.; Madsen, K. Acute and sustained effects of a periodized carbohydrate intake using the sleep-low model in endurance-trained males. Scand. J. Med. Sci. Sports 2019, 29, 1866-1880. [CrossRef] [PubMed]

142. Marquet, L.-A.; Brisswalter, J.; Louis, J.; Tiollier, E.; Burke, L.; Hawley, J.; Hausswirth, C. Enhanced Endurance Performance by Periodization of CHO Intake:" sleep low" strategy. Med. Sci. Sports Exerc. 2016, 48, 663-672. [CrossRef] [PubMed]

143. Gillen, J.B.; Percival, M.E.; Ludzki, A.; Tarnopolsky, M.A.; Gibala, M. Interval training in the fed or fasted state improves body composition and muscle oxidative capacity in overweight women. Obesity 2013, 21, 2249-2255. [CrossRef] [PubMed]

144. Terada, T.; Toghi Eshghi, S.R.; Liubaoerjijin, Y.; Kennedy, M.; Myette-Cote, E.; Fletcher, K.; Boule, N.G. Overnight fasting compromises exercise intensity and volume during sprint interval training but improves high-intensity aerobic endurance. J. Sports Med. Phys. Fit. 2019, 59, 357-365. [CrossRef]

145. Van Proeyen, K.; Szlufcik, K.; Nielens, H.; Ramaekers, M.; Hespel, P. Beneficial metabolic adaptations due to endurance exercise training in the fasted state. J. Appl. Physiol. 2011, 110, 236-245. [CrossRef]

146. Nybo, L.; Pedersen, K.; Christensen, B.; Aagaard, P.; Brandt, N.; Kiens, B. Impact of carbohydrate supplementation during endurance training on glycogen storage and performance. Acta Physiol. 2009, 197, 117-127. [CrossRef]

147. Beaudouin, F.; Joerg, F.; Hilpert, A.; Meyer, T.; Hecksteden, A. Carbohydrate intake and training efficacy-a randomized cross-over study. J. Sports Sci. 2018, 36, 942-948. [CrossRef]

148. Marquet, L.A.; Hausswirth, C.; Molle, O.; Hawley, J.A.; Burke, L.M.; Tiollier, E.; Brisswalter, J. Periodization of Carbohydrate Intake: Short-Term Effect on Performance. Nutrients 2016, 8, 755. [CrossRef]

149. Hulston, C.J.; Venables, M.C.; Mann, C.H.; Martin, C.; Philp, A.; Baar, K.; Jeukendrup, A.E. Training with low muscle glycogen enhances fat metabolism in well-trained cyclists. Med. Sci. Sports Exerc. 2010, 42, 2046-2055. [CrossRef] 
150. Yeo, W.K.; Paton, C.D.; Garnham, A.P.; Burke, L.M.; Carey, A.L.; Hawley, J.A. Skeletal muscle adaptation and performance responses to once a day versus twice every second day endurance training regimens. J. Appl. Physiol. 2008, 105, 1462-1470. [CrossRef]

151. Cochran, C.A.J.R.; Myslik, F.; MacInnis, M.J.; Percival, M.E.; Bishop, D.; Tarnopolsky, M.A.; Gibala, M.J. Manipulating carbohydrate availability between twice-daily sessions of high-intensity interval training over 2 weeks improves time-trial performance. Int. J. Sport Nutr. Exerc. Metab. 2015, 25, 463-470. [CrossRef] [PubMed]

152. Ghiarone, T.; Andrade-Souza, V.A.; Learsi, S.K.; Tomazini, F.; Ataide-Silva, T.; Sansonio, A.; Fernandes, M.P.; Saraiva, K.L.; Figueiredo, R.C.; Tourneur, Y. Twice-a-day training improves mitochondrial efficiency, but not mitochondrial biogenesis, compared with once-daily training. J. Appl. Physiol. 2019, 127, 713-725. [CrossRef] [PubMed]

153. Gejl, K.D.; Thams, L.B.; Hansen, M.; Rokkedal-Lausch, T.; Plomgaard, P.; Nybo, L.; Larsen, F.J.; Cardinale, D.A.; Jensen, K.; Holmberg, H.-C. No Superior Adaptations to Carbohydrate Periodization in Elite Endurance Athletes. Med. Sci. Sports Exerc. 2017, 49, 2486-2497. [CrossRef] [PubMed]

154. Holloszy, J.O.; Coyle, E.F. Adaptations of skeletal muscle to endurance exercise and their metabolic consequences. J. Appl. Physiol. Respir. Environ. Exerc. Physiol. 1984, 56, 831-838. [CrossRef] [PubMed]

155. Larsen, S.; Nielsen, J.; Hansen, C.N.; Nielsen, L.B.; Wibrand, F.; Stride, N.; Schroder, H.D.; Boushel, R.; Helge, J.W.; Dela, F.; et al. Biomarkers of mitochondrial content in skeletal muscle of healthy young human subjects. J. Physiol. 2012, 590, 3349-3360. [CrossRef]

156. Andrade-Souza, V.A.; Ghiarone, T.; Sansonio, A.; Santos Silva, K.A.; Tomazini, F.; Arcoverde, L.; Fyfe, J.; Perri, E.; Saner, N.; Kuang, J.; et al. Exercise twice-a-day potentiates markers of mitochondrial biogenesis in men. FASEB J. 2020, 34, 1602-1619. [CrossRef]

157. Charlot, K.; Pichon, A.; Chapelot, D. Effets de l'entraînement à jeun sur la V ·O2max, l'oxydation des lipides et la performance aérobie chez des jeunes hommes modérément entraînés. Sci. Sports 2016, 31, 166-171. [CrossRef]

158. Burke, L.M.; Ross, M.L.; Garvican-Lewis, L.A.; Welvaert, M.; Heikura, I.A.; Forbes, S.G.; Mirtschin, J.G.; Cato, L.E.; Strobel, N.; Sharma, A.P.; et al. Low carbohydrate, high fat diet impairs exercise economy and negates the performance benefit from intensified training in elite race walkers. J. Physiol. 2017, 595, 2785-2807. [CrossRef]

159. Burke, L.M.; Sharma, A.P.; Heikura, I.A.; Forbes, S.F.; Holloway, M.; McKay, A.K.A.; Bone, J.L.; Leckey, J.J.; Welvaert, M.; Ross, M.L. Crisis of confidence averted: Impairment of exercise economy and performance in elite race walkers by ketogenic low carbohydrate, high fat (LCHF) diet is reproducible. PLoS ONE 2020, 15, e0234027. [CrossRef]

160. Lundby, C.; Montero, D.; Joyner, M. Biology of VO2max: Looking under the physiology lamp. J. Acta Physiol. 2017, 220, 218-228. [CrossRef]

161. Impey, S.G.; Hearris, M.A.; Hammond, K.M.; Bartlett, J.D.; Louis, J.; Close, G.L.; Morton, J.P. Fuel for the work required: A theoretical framework for carbohydrate periodization and the glycogen threshold hypothesis. Sports Med. 2018, 48, 1031-1048. [CrossRef] [PubMed]

162. Van Proeyen, K.; Szlufcik, K.; Nielens, H.; Deldicque, L.; Van Dyck, R.; Ramaekers, M.; Hespel, P. High-fat diet overrules the effects of training on fiber-specific intramyocellular lipid utilization during exercise. J. Appl. Physiol. (1985) 2011, 111, 108-116. [CrossRef] [PubMed]

163. Durkalec-Michalski, K.; Zawieja, E.E.; Zawieja, B.E.; Jurkowska, D.; Buchowski, M.S.; Jeszka, J. Effects of Low Versus Moderate Glycemic Index Diets on Aerobic Capacity in Endurance Runners: Three-Week Randomized Controlled Crossover Trial. Nutrients 2018, 10, 370. [CrossRef] [PubMed]

164. Podlogar, T.; Free, B.; Wallis, G.A. High rates of fat oxidation are maintained after the sleep low approach despite delayed carbohydrate feeding during exercise. Eur. J. Sport Sci. 2020, 1-11. [CrossRef] [PubMed]

165. Heikura, I.A.; Stellingwerff, T.; Burke, L.M. Self-reported periodization of nutrition in elite female and male runners and race walkers. Front. Physiol. 2018, 9, 1732. [CrossRef] [PubMed]

Publisher's Note: MDPI stays neutral with regard to jurisdictional claims in published maps and institutional affiliations. 